\title{
KEYNES'S POLITICS AND ECONOMICS
}

\author{
EDWARD W. FULLER*
}

Fecha de recepción: 28 de abril de 2016

Fecha de aceptación: 12 de febrero de 2017

Resumen: La tesis central de este trabajo es que Keynes perfiló el modelo IS-LM para justificar el socialismo no marxista. Este artículo establece la cronología de las ideas de Keynes para demostrar que creó la economía keynesiana para justificar las creencias políticas que sostenía previamente. Muestra que Keynes puede caracterizarse como un socialista no marxista. Posteriormente, confirma que el modelo IS-LM es la interpretación correcta de la Teoría General. Por último, utiliza las ecuaciones y diagramas de restricción de demanda del modelo IS-LM para ilustrar la justificación económica de Keynes del socialismo no-marxista.

Palabras clave: John Maynard Keynes, modelo IS-LM, socialismo, socialización de la inversión

Clasificación JEL: E12, E22, E32, E52, P20, P26, B22, B24

Abstract: The central thesis of this paper is that Keynes invented the IS-LM model to justify non-Marxist socialism. This paper outlines the chronology of Keynes's ideas to demonstrate that he invented Keynesian economics to justify his previously held political beliefs. This paper shows that Keynes is best described as a non-Marxist socialist. Then the papers confirms that the IS-LM model is the correct interpretation of the General Theory. Finally, the IS-LM demand constraint equations and diagram are used to illustrate Keynes's economic justification of non-Marxist socialism.

Keywords: John Maynard Keynes, IS-LM model, Socialism, Socialization of Investment

* Edward W. Fuller, MBA, is a graduate of the Leavey School of Business. 
JEL Classification: E12, E22, E32, E52, P20, P26, B22, B24

It is a busy life to be a propagandist

J.M. KeYNES 1924A

The precise use of language comes at a late stage in the development of one's thoughts. You can think accurately and effectively long before you can so to speak photograph your thought.

J.M. KeYNES 1933A

\section{I \\ INTRODUCTION}

To fully understand Keynesian economics it is necessary to understand John Maynard Keynes's political beliefs. Most economists try to be value-free and leave politics out of economics, but Keynes was not a value-free economist: «economic theory, was seen by Keynes as being scope-dependent. It had lost all presumptions of neutrality from values... the economist, according to Keynes, had to set explicit objectives beforehand» (Carabelli 1988: 159). Keynes's objective in the General Theory was to justify his previously held political beliefs. To Keynes «economics discussion was ultimately in service to politics» (O'Donnell 1992: 794). His early interest was politics and his political thought inspired his economics: «Keynes developed his political theories long before his economics, and the principles of his economics reflected his politics rather than the other way around» (Fitzgibbons 1988: 54-5). Moreover, his policy recommendations were based on his political views, not his economics. For Keynes politics comes first, policy comes second, and economics comes last: «the purpose of the theory is to provide a rigorous underpinning for a policy position» (Patinkin 1976: 18). In short, «He invented theory to justify what he wanted to do» (Skidelsky 1992: 344). Since Keynes's economics were politically motivated, it is impos- 
sible to completely understand Keynesian economics without understanding Keynes's political views. ${ }^{1}$

II WAS KEYNES A CONSERVATIVE OR A LIBERAL?

There are many different and contradictory interpretations of Keynes's political beliefs. He has been called a conservative, a liberal, and a socialist. Today most interpreters agree that he was not a conservative, but some early supporters of the Keynesian revolution aligned Keynes with conservatism to attract American economists to the new economics. Lawrence Klein claimed, «Keynesian policy is, indeed, a conservative one because it aims to conserve free-enterprise capitalism» (1949: 167; Galbraith 1987: 22). However, Keynes was not a conservative in any sense of the term. In 1925 he wrote, «How could I bring myself to be a Conservative? They offer me neither food nor drink ... It promotes neither my self-interest nor the public good. It leads nowhere; it satisfies no ideal; it conforms to no intellectual standard; it is not even safe» (CW 9: 296-7). He thought that «conservatism is a far greater danger of the near future than a revolutionary socialism» (CW 17: 270). Moreover, he did not want to conserve or save capitalism. Instead, he argued that "private capitalism is an out-of-date institution» and «We need to be slowly reconstructing our social system» (CW 21: 491, 393). As will be shown, he violently opposed capitalism and he wanted to replace capitalism with a social system that was distinctly non-cap-

\footnotetext{
${ }^{1}$ For more on the relationship between politics, policy, and economic theory in Keynes's works, see Backhouse and Bateman (2008: 723; 2010: 20-1), Brunner (1996: 189, 195), Carabelli (1988: 159-3), Clarke (1983: 175; 1988: 3, 78, 88, 102; 1996: 207-8, 210), Cristiano (2014: xx, 52, 122, 235-6), Davenport-Hines (2015: 70, 185), Dillard (1948: 295, 318), Dostaler (1996: 15, 26; 1999), Eshag (1963: 90-1), Felix (1995), Fitzgibbons (1988: 42-5, 96, 197), Garrison (1993: 476), Johnson and Johnson (1978: 27, 30-1), Klein (1949: 31), Lawlor (2006: 9, 80, 179), Lekachman (1966: 59), McKibben (2013), Meltzer (1988: 5, 305), Mini (1991: 102), Minsky (1975: 145), Moggridge (1976: 23, 27-8, 31, 38; 1992: 553), O'Donnell (1989: 180, 209-13; 1992: 778, 783), Patinkin (1976: 9; 1982: 204, 214; 1988: 5472), Perelman (1989: 50), Raico (2008: 167), Robinson (1947: 10), Salerno (1992: 4), Schuker (2014: 454), Schumpeter (1946: 501), Sheehan (2009: 189, 175, 232, 272), and Skidelsky (1983: xx; 1991: 104; 1992: 173, 271, 405, 425, 539, 546; 2000: 152, 155, 377).
} 
italistic. Keynes was not a political conservative and he did not want to conserve free-enterprise capitalism.

The traditional view is that Keynes was a liberal. Keynes's friend and official biographer Roy Harrod states, «He was violently opposed to laissez-faire.... he is a Liberal» (1951: 192). Robert Skidelsky argues that «Keynes was a lifelong liberal» and «He was the last of the great English Liberals» (2009: 157; 1992: xv). Interpreters who insist that Keynes was a liberal tend to base their argument on his early membership in Britain's Liberal Party. He was involved in the Liberal Party from October 1902 until the demise of the party in 1929. By 1939 he still fantasized about the revival of British left-liberalism: «There is no one in politics today worth sixpence outside the ranks of liberals except the post-war generation of intellectual Communists under thirty-five» (CW 28: 494-5). Keynes's early activity in the Liberal Party has led many scholars to argue that he was a liberal.

Keynes's membership in the Liberal Party does not mean that he was a liberal, however. Not all members of Liberal Parties are liberals, and Keynes himself thought that party affiliation is a poor indicator of political thought (Keynes 1924b; CW 20: 476). His political views were on the very far left of the political spectrum. He stated, «The republic of my imagination lies on the extreme left of celestial space» (CW 9: 309). By 1920 Britain's Liberal Party had abandoned the laissez-faire liberalism of Robert Peel, Richard Cobden, and William Gladstone, but the party had not gone far enough for Keynes. He wanted to move the Liberal Party to the extreme left: «Our own sympathies are for a Liberal party which has its center well to the left» and «Liberals must move towards Labour and not in the other direction» (CW 18: 125; Keynes 1923). Keynes was a man of the very far left and there were two parties of the left in Britain, the Liberal Party and the Labour (Socialist) Party. Interpreters who classify Keynes as a liberal commonly exaggerate his devotion to the Liberal Party and downplay his close ties to the Labour Party. There really was no Liberal Party in Britain after the 1929, so he worked closely with the socialist Labour Party throughout the 1930s and 1940s. He supported the establishment of the Labour party in January 1904; he served as economic advisor to Britain's first Labour government in the early 1930s; he voted La- 
bour in 1935 just before the General Theory was published; and from 1945 to his death he was chief economic advisor to the socialist Labour Chancellor Hugh Dalton. Just after the General Theory was published he wrote, «I scarcely know where I stand. Somewhere, I suppose, between Liberal and Labour, though in some respects to the left of the latter» (CW 21: 372-3). Keynes was an active supporter of the socialist Labour Party while he was writing the General Theory. ${ }^{2}$

Keynes was not a liberal in the traditional sense of the term. The term liberal comes from Latin word «liber», meaning «free». Etymologically, liberalism is the political philosophy of liberty and freedom. But for Keynes, «It is not true that individuals possess a prescriptive "natural liberty"... individuals acting separately to promote their own ends are too ignorant or too weak» (CW 9: 2878). Liberty is the absence of violence against private property, so private property is the central notion of liberalism: «The program of liberalism, therefore, if condensed into a single word, would have to read: property» (Mises 1927: 2). Liberalism is the political philosophy of liberty based on private property, but throughout his career Keynes consistently advocated the systematic violation of private property rights by government. His disregard for private property rights means that he was not an economic liberal in the tradition of Adam Smith, Thomas Jefferson, Jean-Baptiste Say, or Ludwig von Mises. In fact, Keynes was the twentieth century's most important and influential opponent of economic liberty and private property rights. Interpreters who insist that Keynes is a liberal must substantially redefine liberalism to exclude liberty and property. He can only be aligned with liberalism by contriving a

2 O'Donnell notes, «It was with the "Socialist" groupings that his general sympathies lay» (1999: 160). Roy Harrod is largely responsible for creating the myth that Keynes was a conventional, liberal economist. Skidelsky accuses Harrod of «covering up and planting false trails» (1983: xxv). Politically, «Harrod concealed the drift of Keynes's sympathies from the Liberal Party to Labour in the 1930s» and «felt it his duty to protect the public name of Keynes from association with the socialists» (Toye 2005: 124; Newton 2001: 24). On Harrod's problematic biography, see Backhouse and Bateman (2008: 3; 2011a: 163-64), Clarke (1996: 205-06; 2009: 11, 28-29, 40), Dostaler (2007: 136), Fitzgibbons (1988: 92-4), Holroyd (1994: xxii-xxiii), Martin (1970: 41), Newton (2001), Skidelsky (1983: xx-xxviii, 128; 2000: 492-5), and Toye (2005). See Dostaler (2007: 104-26) for an overview of British politics during Keynes's life. 
«new liberalism» which endorses the systematic violation of property rights. By definition, however, liberty means that a person's property rights are not violated. «New liberalism» is a contradictio in adjecto; it is anti-liberty liberalism. Semantics aside, Keynes did not invent his economic theory to justify the political philosophy of liberty and property rights, i.e. liberalism.

\section{III}

\section{WAS KEYNES A SOCIALIST?}

The mainstream view is that Keynes rejected socialism (Harrod 1951: 333; Skidelsky 2009: 135). Still, most interpreters acknowledge socialist undertones in Keynes's works and his tremendous influence on socialists is universally recognized. ${ }^{3}$ Some important Keynes scholars go even further and argue that he was a socialist. Donald E. Moggridge, the general editor of The Collected Writings of John Maynard Keynes, aligns him with socialism: «By his own admission, Keynes lay at the "liberal socialist" end of the broad spectrum of political and social thought that runs to Ludwig von Mises and Hayek and successors such as Milton Friedman at the other» (1976: 38). Rod M. O'Donnell, the editor of The Further Collected Writings of J.M. Keynes, argues that he was a socialist: «Keynes advocated a particular form of socialism over approximately two decades» (1999: 172). Most economists are skeptical that Keynes was a socialist, so it is necessary to review what he actually said about socialism.

\footnotetext{
${ }^{3}$ See Barnett (2013: 115), Brunner (1996: 194, 201), Clarke (1988: 13, 160, 221), Cranston (1978: 101, 111), Cristiano (2014: 19, 155), Davenport-Hines (2015: 234), Dillard (1948: 2), Fitzgibbons (1988: 163), Harcourt and Kerr (2009: 58, 74), Hansen (1936: 682), Holland (1977: 67), Hyams (1963: 125; 1974: 232), King (2002: 34, 49-50, 92, 119, 225), Lambert (1963: 362), Laurent (2001: 81n22, 82n23), Lekachman (1985: 37), Meltzer (1988: 12, 189), Minsky (1975: 145-6), Moggridge (1992: 469), Pimlott (1985: 224), Robinson (1947: 46), Rowse (1932, 1936), Skidelsky (1978: 83; 2009: 165), Toye (1999: 269), Walker (1988: 88-9), Webb (1985: 103), and Wright (1979: 186, 196). The socialist G.D.H. Cole wrote, «most of the non-Marxist socialist economists swallowed Keynes whole, and became his most fervent disciples» (1950: 49).
} 
Keynes developed his views on socialism decades before he published any major works in economics. He was already deeply interested in politics before he entered the University of Cambridge in 1902, and as an undergraduate he was an energetic member and leader of the university political clubs. By 1906 he was involved with the socialist movement at Cambridge (Holroyd 1994: 124). Keynes was an early member of the Cambridge University Fabian Society, and the socialist Bernard Shaw spoke at that club on 24 October 1907. The following day Keynes wrote to Lytton Strachey, «Mr Bernard Shaw converted us all to Socialism last night» (Keynes 1907). ${ }^{4}$ He publically advocated socialism for the first time on 7 February 1911 when he spoke with Sidney Webb in support of a motion "That the progressive re-organisation of society on the lines of Collectivist Socialism is both inevitable and desirable» (Keynes 1911). Later that year Keynes's father recorded in his diary that «Maynard avows himself a socialist» (quoted in Moggridge 1992: 190). In short, Keynes used the term socialism to describe his political views before the outbreak of the First World War.

Keynes's support of socialism only intensified after the war. During 1922 he wrote, «An extraordinary experiment in socialism is in course of development. I think there may be solid foundations on which to build a bridge» (CW 17: 420). He enthusiastically predicted in 1924 that the «true socialism of the future will emerge, I think, from an endless variety of experiments» (CW 19: 222). On 8 June 1924 he drafted an outline for a book called Prolegomena to a New Socialism (Keynes 1924c). In March 1925 he noted, «The Bank of England is a type of that socialism of the future which is in ac-

\footnotetext{
${ }^{4}$ George Bernard Shaw was a leader of the socialist Fabian Society and a fervent supporter of Lenin, Stalin, Hitler, and Mussolini. Keynes was aware that «B. Shaw blesses the fascists» (Keynes 1927a). He wrote, «I thought H.G. [Wells] on G.B.S. too revengeful (because of Mussolini I suppose). If I had written such things, I should have written them with more affection» (Keynes 1927b). According to Kingsley Martin, «Maynard Keynes wrote that [Wells and Shaw] were our two schoolmasters; Wells was the [chemistry] master, while Shaw taught divinity» (1970: 94). Throughout his life Shaw recommended a policy in which «each citizen appear before a Board once in seven years, and defend his claim to live. If he could not, then he should be put into a lethal chamber» (quoted in Yde 2013: 11, 106). In 1927 Keynes wrote about his dear friend, «What a debt every intelligent being owes to Bernard Shaw!», and in 1946 he noted the «love and honour in which I hold G.B.S.» (CW 9: 320; CW 10: 381).
} 
cord with British instincts of government, and which - perhaps one may hope- our Commonwealth is evolving within its womb» (CW 19: 348). ${ }^{5}$ By 1926 Keynes developed a close friendship with Sidney and Beatrice Webb, Britain's leading socialists. Virginia Woolf observed, «Lydia and Maynard are both completely under the sway of the Webbs.... [the great Keynes] is at [Beatrice Webb's] feet» (Woolf 1978: 289). His friendship with the Webbs drove his scorned lover Duncan Grant to write, "Socialism is now going to become for them a moral excuse for meanness» (Grant 1926, 3). In 1926 Keynes declared, «I have played in my mind with the possibilities of greater social changes than come within the present philosophies of, let us say, Mr Sidney Webb, Mr Thomas, or Mr Wheatley.... Socialists, many Liberals today would not find uncongenial» (CW 9: 309). ${ }^{6}$ He concludes, «I think that it would be for the health of the [Liberal] party if all those who believe... that the coming political struggle is best described as capitalism versus socialism, and, thinking in these terms, mean to die in the last ditch for Capitalism, were to leave us» (CW 9: 310). On 3 August 1928, after publication of the Labour Party's platform Labour and the Nation, he praised the socialist's «system of public control» and argued that the

${ }^{5}$ Keynes's demand for complete government control of money and banking is consistent with socialism. Free market capitalism requires separation of money and banking from the State, while socialism requires total State control of money and banking. The Communist Manifesto calls for «Centralization of credit in the hands of the state, by means of a national bank with state capital and an exclusive monopoly» (Marx 1848: 230). Vladimir Lenin writes, «without big banks socialism would be impossible. The big banks are the "state apparatus" which we need to bring about socialism ... A single State Bank, the biggest of the big ... will constitute as much as ninetenths of the socialist apparatus» (Lenin CW 26: 108).

${ }^{6}$ O'Donnell notes, «Webb, Thomas and Wheatley were socialists» and Keynes's «vision lay beyond the Fabian Socialism of Webb» (1989: 377; 1991: 5). In 1931 Keynes merged the newspaper he owned with the New Statesman, a Fabian paper founded by the Webbs. Keynes was chairman of the New Statesman and Nation until his death, and that paper was «unequivocally socialist» (Smith 1996: 156; Hyams 1963: 125). On 18 July 2013, the New Statesman admitted that their former chairman was a socialist: «Shaw, Keynes and Wells [each] argued for their own vision of socialism in the UK» (Taunton 2013). By 1936 the Webbs published Soviet Communism in which «Soviet Russia was very much like an idealized version of the Fabian State» (Hession 1984: 277). Keynes said that Soviet Communism is «an enthralling work» with «extraordinarily important and interesting information» (CW 21: 333-4). Keynes viewed Beatrice Webb as «the greatest woman of the generation» (Keynes 1943). 
«Lib[eral] and Lab[our] [Parties] shall cooperate. For there is a large enough measure of agreement on what to do next» (Keynes 1928a). Labour and The Nation was concerned with «transforming Capitalism into Socialism» and «the establishment of the Socialist Commonwealth» (Labour Party 1928: 3, 14). On 23 October 1929 he outlined his «type of social[ist] action for the future» in a speech called Social Reform as the New Socialism (Keynes 1929). He declared, «modern economic organisation is liable to produce unintended and undesired results unless it is controlled from the centre» (Keynes 1929). At an Economic Advisory Council meeting on 1 June 1930 Keynes described himself as «the only socialist present» (quoted in Dalton 1986: 115, emphasis added). Later that year he wrote, «I do not see what practical socialism can mean for our generation in England, unless it makes much of [Oswald Mosley's] manifesto its own —-this peculiar British socialism» (CW 20: 475). ${ }^{7}$ These passages shows that Keynes was a socialist long before he published any major works on economics theory.

Keynes published his first major work in economics, A Treatise on Money, on 31 October 1930 at the age of forty-seven. Earlier that year Keynes claimed, «we shall do well to turn to what I should call the liberal solution, or what I have heard Mr Ramsay MacDonald call the socialist solution» (CW 20:12). He wrote A Treatise on Money to underpin this socialist solution: «The new book on Monetary Theory which I have in preparation will, I am hopeful, throw much new light on my fundamental arguments in favour of the dogmas to which I have rashly given utterance without sufficiently

${ }^{7}$ Oswald Mosley was the founder of the British Union of Fascists. To Mosley, «National Socialism and Fascism in my view are the same Movement» (1936: 9). Skidelsky writes, «Mosley was a disciple of Keynes ... Keynesianism was his great contribution to fascism [National Socialism]. It was Keynesianism which in the last resort made Mosley's fascism [National Socialism] distinctively English» (1975: 302). Clarke writes, «Mosley represented the sort of fresh thinking in economic policy which Keynes thought necessary» (1988: 221). Mosley was the paid agent of Hitler and Mussolini, and in 1936 Mosley secretly married Diana Mitford at the home of Joseph Goebbels where Hitler was one of six guests (Dorrill 2007: 376-8, 393). Virginia Woolf recorded at the time Keynes was writing the General Theory, «We are going over to Tilton, to be converted by Maynard to what I suspect of being a form of Fascism [National Socialism]» (1985: 222). Keynes was widely regarded as a fascist economist in the Soviet Union (Letiche 1971: 444). 
substantiating them» (Keynes 1925). In A Treatise on Money he contemplates «socialistic action by which some official body steps into the shoes which the feet of the entrepreneurs are too cold to occupy» (CW 6: 335). The economic theory in A Treatise on Money was a failure, but failure to rationalize socialism with economic theory never made him to abandon socialism. ${ }^{8}$ In a 13 December 1931 speech to the Society for Socialist Inquiry and Propaganda, called A Survey of the Present Position of Socialism, he said, «I should like to define the socialist programme as aiming at political power ... My goal is the ideal ... it will have to be on the basis of increased resources, not on the basis of increased poverty, that the great experiment of the ideal republic will have to be made» (CW 21: 34). Around this time Keynes joined the New Fabian Research Bureau as an associate member (Cole 1961: 235). That organization was the research affiliate of the Society for Socialist Inquiry and Propagan$\mathrm{da}$, and its purpose was «to produce socialist inspired reports» (Cole 1948: 282-3; Pugh 1984: 158). Keynes was a socialist for over two decades before he started the General Theory.

Keynes started formulating the General Theory in the summer of 1931. Chapter 24 of the General Theory was called «Socialism» in the 1932 draft, and the views expressed in Chapter 24 mirror the socialist views he held in the 1920s (CW 29: 50). He voted for the socialist Labour Party three months before the General Theory was published, and that party's official platform was For Socialism and Peace. This comprehensive socialist policy program aimed at «creating a new social order and a British Socialist Commonwealth» (Labour Party 1934: 29). After the General Theory Keynes continued advocating socialism. He lectured at the Fabian Society in 1935 and 1936, and Beatrice Webb recorded in her diary that he desired «a modified socialism» (quoted in Webb 1985: 371). During 1939 he

\footnotetext{
${ }^{8}$ Keynes boasted that his theory in A Treatise on Money is a «mathematical certainty» and «I am ready to have my head chopped off if it is false!» (CW 20:356, 350-1). But Clarke notes that «Keynes's abandonment of the Treatise, so soon after publication, is remarkable» (1988: 229). Patinkin writes about $A$ Treatise on Money, «I can (from the viewpoint of macroeconomic theory) see little profit in reading it.... it is not a good book» (1976: 25). On the macroeconomics of A Treatise on Money, see Dimand (1988: 21-86), Klein (1949: 15-30), Laidler (1999: 130-54), Meltzer (1988: 61-114), Moggridge (1992: 484-90), Patinkin (1976: 35-53), and Shackle (1974: 15-32).
} 
wrote, «The question is whether we are prepared to move out of the nineteenth century laissez-faire into an era of liberal socialism» (CW 21: 500). On 21 February 1940 he told the Fabian Society that his How to Pay for the War proposal «is the right Socialist solution... It is for the state to say how much a man is entitled to spend out of his earnings» (Keynes 1940). These passages indicate that from 1907 onwards Keynes aligned himself with socialism and used the term socialism to describe his political philosophy. The chronology outlined above indicates that Keynes's political views inspired his economic theory, not vice versa.

Socializing investment is Keynes's main policy recommendation. In the General Theory Keynes claims that «a somewhat comprehensive socialisation of investment will prove the only means of securing an approximation of full employment» (CW 7: 378, emphasis added). The chronology shows that his recommendation of socializing investment was based on his socialist political beliefs, not his General Theory. By 1910 he exclaimed, «there are a great many fools amongst our businessmen» (Keynes 1910). On 7 June 1924, over a decade before the General Theory was published, he wrote, «the state encouragement of new capital undertakings... is becoming an inevitable policy» (CW 19: 229). The next day he recorded «Investment of Fixed Capital» as one of the «Chief preoccupations of the State» in Prolegomena to a New Socialism (Keynes 1924c). During 1926 he wrote, «I do not think that these matters [investment] should be left entirely to the chances of private judgment and private profits» (CW 9: 292). That year he inspired the socialist Labour Party to include centrally planned investment in their program, Socialism in Our Time (Walker 1988: 84). By 1928 he called for the formation of his National Investment Board «to mobilise and to maintain the supply of capital and the stream of savings without which capital development is impossible» (Keynes 1928b: 69). In A Treatise on Money he concludes, «Perhaps the ultimate solution lies in the rate of capital development becoming more largely an affair of the state, determined by collective wisdom and long views» (CW 6: 145). These passages show that Keynes's recommendation to socialize investment was based on his previously held socialist views, not the General Theory he invented years later. 
The failure of $A$ Treatise on Money did not change Keynes's recommendation of socializing investment. During 1931 he predicted that «there will be no means of escape from prolonged and perhaps interminable depression except by direct state intervention to promote and subsidize new investment» (CW 21: 60). Importantly, he acknowledged that his policy of socializing investment is a socialist policy. On 24 September 1932 he wrote, the «chief problem would be to maintain the level of investment at a high enough rate to ensure the optimum level of employment... The grappling with these central controls is the rightly conceived socialism of the future» (CW 21: 137, emphasis added). Moreover, Britain's socialist party confirmed that Keynes's policy of socialized investment is a socialist policy by making Keynes's National Investment Board a central part of the 1934 Labour Party platform, For Socialism and Peace (Pimlott 1985: 218; Walker 1988: 123). As noted, Keynes voted for this socialist program. During a 1934 lecture at Cambridge he declared, «Private capitalism is in this matter an open scandal and grossly inefficient. There may be no remedy except the direction of long-term investment by the State» (1988: H32). In the General Theory he says, «I conclude that the duty of ordering the current volume of investment cannot safely be left in private hands» (CW 7: 320).

After the General Theory Keynes continued advocating the socialization of investment. During 1936 he declared, «investment is a matter which cannot be left solely to private decision", and his «Board of National Investment would in one way or another control by far the greater part of investment» (CW 29: 232; CW 14: 49). In 1937 he wrote, «Now is the time to appoint a board of public investment to prepare sound schemes» (CW 21: 394). During the Second World War he advocated the creation of the Board for International Investment as part of his seminal Currency Union plan (CW 25: 59, 190). In addition to promoting the international socialization of investment, this plan involved the creation of a world central bank and «the construction of the future government of the world» (CW 25: 94). In 1943 he recommended that the government carry out at least «two thirds or three-quarters of total investment» (CW 27: 322). He wanted «the bulk of investment ... under public or semi-public control» (CW 27: 326). Just before his death he ad- 
mitted that the theme of socialized investment «is a very ancient one with me» (Keynes 1946). Keynes consistently advocated socializing investment from 1924 until the end of his life, and he acknowledged that socializing investment is a socialist policy. ${ }^{9}$ In summary, the chronology shows that Keynes's socialist political and policy views came first, and the economic theory came after to justify his previously held socialist views.

\section{IV \\ KEYNES, MARX, AND SOVIET COMMUNISM}

Keynes described himself as a socialist and he recommended socialist policies, so how can interpreters argue that he was not a socialist? Interpreters have argued that Keynes was not a socialist because during the Cold War socialism meant Marxism and government ownership of the means of production. The standard interpretation is that he violently opposed Marxism. He claimed that Marxian economics is "obsolete», "scientifically erroneous», and «nothing but out-of-date controversialising» (CW 9: 258; CW 28: 42). Furthermore, he argued that «it is not the ownership of the instruments of production which it is important for the State to assume» (CW 7: 378). During the Cold War advocates of the Keynesian Revolution used such passages to distance Keynes from socialism. Still, there is no doubt that he consistently aligned himself with socialism. To fully understand Keynes's politics it is nec-

\footnotetext{
9 According to Skidelsky, «his own policies could be shown to be consistent with a range of socialist policies, notably central controls on investment» (1992: 437). Many interpreters minimize Keynes's call to socialize investment by downplaying Chapter 24 of the General Theory (Hansen 1953: 215; Patinkin 1990: 226). However, Patinkin admits that Chapter 24 contains «the fundamental policy conclusion of the General Theory — the advocacy of direct government investment» (1976: 136). Meltzer points out that Keynes's «principal recommendation — public direction of investment- is repeated several times in the General Theory and was not a new idea... The views expressed in the 1920s closely parallel the views expressed in Chapter 24» (1988: 182). Skidelsky agrees that «From 1924 Keynes knew what he wanted to do and, in very broad terms, why» (1992: 173).
} 
essary to compare and contrast Keynesian socialism with Marxism and Soviet communism.

The traditional view is that Keynes despised Soviet communism in Russia, but this traditional view is incomplete. Instead, his opinion of Soviet communism was mixed and fluctuating. At first he celebrated the Bolshevik Revolution. In December 1917 Keynes declared that «the only course open to me is to be buoyantly bolshevik», and during February 1919 he again admitted to «Being a Bolshevik» (CW 16: 266, 267). In 1922 his future wife, a Russian who also had «natural sympathies... for socialism», was smitten by his «sympathy for Russia» (Mackrell 2008: 259; Lopokova 1922: 35). By 1925 his opinion of Soviet communism was conflicted. He supported the Bolsheviks' goals but he opposed their tactics: «there is much in Russia to make one pray that one's own country may achieve its goal not in that way... I should like to give Russia her chance; to help and not to hinder... beneath the cruelty and stupidity of New Russia some speck of the ideal may lie hid» (CW 9: 2701). He admired Soviet communism «not as an improved economic technique, but as a religion», and he thought that «Russian Communism does represent the first confused stirrings of a great religion» (CW 9: 267, 269). On 27 October 1927 he wrote to his wife, «I was much flattered last night by getting the enclosed invitation from the Bolsheviks to go to Russia next month to celebrate the tenth year of the Republic.... The idea is very attractive» (Keynes 1927a). Four months after publishing the General Theory he announced, «Until recently events in Russia were moving too fast and the gap between the paper professions and the actual achievements was too wide for a proper account to be possible. But the new system is now sufficiently crystallised to be reviewed. The result is impressive» (CW 28: 333). Keynes had a love-hate relationship with Soviet communism.

There are many striking similarities between Keynes's vision and Marx's vision. First, Keynesian socialism and Marxian socialism have the same «emotional and ethical essence»: «Leninism is absolutely, defiantly non-supernatural, and its emotional and ethical essence centres about the individual's and the community's attitude towards the Love of Money» (CW 9: 259). Like Karl Marx and Vladimir Lenin, Keynes believed that capitalism was immoral 
and he thought that the love of money was the chief moral problem with capitalism. He argued that «the moral problem of our age is concerned with the love of money», and «the love of money is detestable» (CW 9: 268, 331). Moreover, he deplored financial accounting and corporate finance (economic calculation). He complained that under capitalism men's minds are «beset by false analogies from an irrelevant accountancy.... But once we allow ourselves to be disobedient to the test of an accountant's profit, we have begun to change our civilization» (CW 21: 241-2). He praised the socialist goal of abolishing the love of money and the wealth maximizing goal of investors: «Money-making and money-accumulating cannot enter into the life-calculations of a rational man who accepts the Soviet rule in the way in which they enter into ours. A society of which this is even partially true is a tremendous innovation» (CW 9: 261). Keynes and Marx held the same socialist view of the love of money and economic calculation. ${ }^{10}$

Keynes's attitude towards interest is consistent with socialism. According to the non-Marxist socialist Silvio Gesell, «The abolition of unearned income, of so-called surplus-value, also called interest and economic rent, is the immediate economic aim of every socialistic movement» (quoted in Dillard 1942: 64). Keynes attacked «unearned increments» in 1904 and his contempt for the interest earning bondholder, or rentier, was entrenched by 1922 (1904; CW 18: 71-5). He proclaimed in his historic 4 December 1933 lecture, «The evils of capitalism could be gradually and effectively eliminated by this process of the evaporation of the rate of interest» (1988: G36). In the General Theory he calls for «the euthanasia of the rentier, and, consequently, the euthanasia of the cumulative oppressive power of the capitalist to exploit the scarcity-value of capital. Interest to-day rewards no genuine sacrifice, any more than does the

${ }^{10}$ A key economic error of Marxism is to ignore the time value of money (Bohm-Bawerk 1890: 342-53). Keynes did not ignore the time value of money, but he adopted a flawed approach. In Keynes's flawed approach to the time value of money, investors use the marginal efficiency of capital in economic calculation. However, «Keynes' [marginal efficiency of capital] did not give an investment demand function according to the maximum present wealth criterion of choice by investors» (Alchian 1955: 941). The most glaring problems in Marxian economics and Keynesian economics are related to the time value of money. See Fuller (2013). 
rent of land» (CW 7: 376). Keynes wanted to eliminate interest like all socialists, and he wanted to do so long before he developed his economic justification in the General Theory.

Keynes was a utopian, and his utopianism was central to his politics and economics. ${ }^{11}$ He claimed that his utopianism was grounded in economic analysis, but he was a utopian decades before the General Theory. During 1938 Keynes boasted that since his youth he had been «among the last of the Utopians» (CW 10: 447). Before he started formulating the General Theory, he wrote,

the economic problem... the problem of want and poverty... is nothing but a frightful muddle, a transitory and an unnecessary muddle. For the western world already has the resources and the technique, if we could create the organisation to use them, capable of reducing the economic problem, which now absorbs our moral and material energies, to a position of secondary importance... the day is not far off when the economic problem will take the back seat where it belongs, and that the arena of the heart and head will be occupied, or reoccupied, by our real problems - the problems of life and of human relations, of creation and behaviour and religion. And it happens that there is a subtle reason drawn from economic analysis why, in this case, faith may work. For if we consistently act on the optimistic hypothesis, this hypothesis will tend to be realised; whilst by acting on the pessimistic hypothesis we can keep ourselves for ever in the pit of want (CW 9: xviii, emphasis added)

At Cambridge on 25 November 1935 he declared, "Capital should now not be scarce... if we had full employment and with the existing propensity to consume, we should in 25-30 years have constructed all capital required. We would increase the quantity of capital until it has ceased to be scarce» (1989: 179-80). As a utopian,

11 For more of Keynes's utopian writings, see (CW 7: 220-1; CW 9: 321-32; CW 21: 37-8; 1988: G37-8, H40, J36). Keynes's utopianism is noted by Brunner (1996: 208), Davis (1994: 172), Dostaler (2007: 99), Fitzgibbons (1988: 68, 191), Fletcher (2008: 171, 175), Freidman (2008: 126), Garrison (1993: 481), Hansen (1953: 215), Hession (1984: 375), Lambert (1963: 503), Meltzer (1988: 185), Mini (1991: 170, 190), Moggridge (1992: 455), O'Donnell (1989: 291-4), Raico (2008, 171-3), Salerno (1992: 18), and Skidelsky (1992: 234-8; 2000: 478; 2009: 164, 135). 
Keynes held the fundamental economic thesis of all socialists: «The fundamental economic thesis common to all socialist groups is that there is a potential plenty» (Mises 1990: 208). Keynes did not think that scarcity was an inevitable fact of the world. He thought that scarcity was artificial and he promised that socializing investment will abolish scarcity: «The economic problem is not too difficult to solve. If you will leave that to me, I will look after it» (CW 28: 34). Like Marx's utopia, Keynes's utopia was a paradise of leisure on Earth with an unlimited abundance of goods. Keynes's utopian vision of «an age of leisure and abundance» is consistent with socialism (CW 9: 328).

Keynes believed that socializing investment will transform human nature. As noted by Karl Brunner, «The socialist vision is usually based on the assumption of a perfectly malleable human nature» (1996: 202). Keynes assured that «the central control of investment ... will tend to produce a better kind of society on ideal grounds» (CW 21: 36-7).

There are changes in other spheres too which we must expect to come. When the accumulation of wealth is no longer of high social importance, there will be great changes in the code of morals. We shall be able to rid ourselves of many of the pseudo-moral principles which have hag-ridden us for two hundred years, by which we have exalted some of the most distasteful of human qualities into the position of the highest virtues. We shall be able to afford to dare to assess the money-motive at its true value (CW 9:329)

Not only will socializing investment create an economic utopia, but socializing investment will create an ethical utopia. Human nature will be transformed, or transmuted (CW 7: 374). Instead of being possessed by the love of money and economic calculation, individuals will be liberated to focus on «truth, beauty, power, affection, and touch» (Keynes 1906). Like Marx and many other socialists, Keynes promised that his brand of socialism will create a New Socialist Man.

Keynes's attitude towards property rights indicates that he is a socialist. Capitalism is a social system based on private property rights. This means that capitalism is based on a universal rule of conduct: no person may violate another person's private property 
rights. But Keynes did not believe in universal rules of conduct. In fact, $A$ Treatise on Probability (1921) is his intellectual justification for violating universal rules like private property rights (CW 10: 445). In 1938 he admitted, «We entirely repudiated a personal liability on us to obey general rules [i.e. property rights].... We were, that is to say, in the strict sense of the term, immoralists.... I remain and always will remain an immoralist» (CW 10: 446-7). Capitalism is based on the universal principle of private property, but Keynes rejected universal principles: «I am afraid of "principle"» and "what a very odd, and sometimes terrible, thing are strict principles!» (CW 20: 379; CW 10: 234). Opposed to the universal principle of private property and the rule of law, he advocates expediency and unlimited government discretion. ${ }^{12}$ All types of socialism share a common feature: a government policy of systematically violating private property rights. Capitalism involves the strict recognition and enforcement of property rights, whereas all forms of socialism involve the institutionalized violation of property rights. The policy of socializing investment entails the organized violation of investors' property rights. To Keynes, the systematic violation of private property rights is not an ethical problem because individuals do not have universal, absolute rights: «There is no "compact" conferring perpetual rights on those who Have or on those who Acquire» (CW 9: 287). Keynes's policy of systematically violating property rights by socializing investment qualifies him as a socialist. ${ }^{13}$

${ }^{12}$ Keynes's advocacy of total government discretion, and consequent rejection of the rule of law, is consistent with socialism: «the rule of law and socialism are incompatible» and «Socialism lacks any principles of individual conduct» (Hayek 1960: 357n64; 1979: 152). On Keynes's view of general rules, principles, expediency, and discretionary governance, see Bateman (1988: 1100), Clarke (1998: 42; 2009: 34), Cristiano (2014: 57), Davenport-Hines (2015: 49, 80, 130), Dostaler (2007: 21), Holroyd (1994: 91), O'Donnell (1989: 108-12, 133; 1991: 6; 1999: 165), Raico (2007: 170-1), and Skidelsky (1983: 152-5). On Keynes's rejection of natural law and natural rights, see Dostaler (2007: 82), Lambert (1963: 494), and O'Donnell (1989: 286; 1991: 6).

${ }_{13}$ There are three points commonly used to distance Keynes's call for the socialization of investment from socialism. First, Keynes did not recommend socializing the consumption component of aggregate demand. However, Keynes knew that «It is not possible to control production without controlling consumption in an equally drastic manner» (CW 16: 114). Second, it is argued that Keynes only wanted to control the volume of investment, not the direction. Still, «investment takes specific forms and 
Keynes and Marx shared a similar vision, but Keynes believed that Marxian economics was totally flawed. Of course, there are similarities between Marxian economics and Keynesian economics. Marx and Keynes rejected Say's Law and the Quantity Theory of Money, and the General Theory is sympathetic to the Labor Theory of Value (CW 7: 213). Like Marx, Keynes thought that chronic economic stagnation was an inevitable feature of the free market economy and he blamed chronic stagnation on the "functionless» capitalist-investor (CW 7: 376). ${ }^{14}$ Despite the similarities, Keynes rejected Marx's economic analysis long before he developed an alternative theory. In 1925 he said, «How can I accept a doctrine which sets up as its bible, above and beyond criticism, an obsolete economic textbook which I know to be not only scientifically erroneous but without interest or application for the modern world?» (CW 9: 258). He declared, «Marxian socialism must always remain a portent to the historians of Opinion - how a doctrine so illogical

one cannot normally control volume without affecting direction» (O'Donnell 1999: 171). Third, it is argued that he advocated central control instead of government ownership of the means of production. However, ownership means exclusive control over a scarce resource. Thus, «Limitation of the rights of owners as well as formal transference is a means of socialization» (Mises 1922: 45; 1927: 39; 1949: 678-80). Central control is economically equivalent to ownership. Thus, Joseph Schumpeter defines socialism as «an institutional pattern in which the control over means of production and over production itself is vested with a central authority» (1943: 167). To Friedrich Hayek, socialism is «any collectivist control of productive resources» (1948: 131). Control requires the violation of private property rights, so Jesus Huerta de Soto writes, «socialism is any organized system of institutional aggression against entrepreneurship» (2010: 85).

${ }^{14}$ Keynes's collaborator Joan Robinson says, «Many refinements and complications... neglected by Marx, are elaborated in the Keynesian theory, but the main outline is clearly to be seen in Marx's analysis» (1966: 66). Preston notes that Keynes's "vision is astonishingly like Marx's picture of communist society», and Mini writes that «Keynes is more radical than Marx» (1987: 158; 1991: 187). Dostaler points out the «mutual esteem between Lenin and Keynes... [Lenin] considered that Keynes offered penetrating analysis of contemporary economic problems.... Trotsky had also offered positive comments on Keynes» (2012: 255). Marxo-Keynesians argue that «Keynes might have developed his 1936 General Theory earlier and better if only, like Michael Kalecki, Keynes had known the works of Marx» (Samuelson 1983: 176). On the relationship between Keynes and Marx, see Alexander (1940), Dillard (1984), Dostaler (2012), Fan-Hung (1939), Fitzgibbons (1988: 78-80, 123-9), Harcourt and Kerr (2009: 3356), Klein (1949: 130-4), Letiche (1971), Milgate (1982: 6), Sardoni (1997), and Sweezy (1946). Patinkin rejects that Marxians anticipated the General Theory (1982: 58-92). 
and so dull can have exercised so powerful and enduring an influence over the minds of men, and through them, the events of history» (1926: 47-8). By 1942 he still believed that Marx «had a penetrating and original flair but was a very poor thinker indeed» (Keynes 1942). To Keynes, Marx's economic analysis did not successfully justify Marxist socialism.

Keynes opposed Marx's class analysis. It is widely acknowledged that «he was a political elitist» (Fitzgibbons 1988: 185). ${ }^{15}$ After Keynes spoke at a socialist summer school in 1926, Beatrice Webb observed that «He is contemptuous of common men» (1985: 94). He believed that «the middle class and even the upper class is very much superior to the working class» (Keynes 1928a). He was a member of the British elite and he thought that the bourgeoisie is better than the proletariat. In 1925 he wrote, «If I am going to pursue sectional interests at all, I shall pursue my own... the Class war will find me on the side of the educated bourgeoisie» (CW 9: 297). His elitism led him to reject Marx's proletarian socialism: «How can I adopt a creed which, preferring the mud to the fish, exalts the boorish proletariat above the bourgeoisie and the intelligentsia, who with all their faults, are the quality in life and surely carry the seeds of all human achievement?» (CW 9: 258). In contrast to Marx's proletarian socialism, Keynes advocated elitist socialism. ${ }^{16}$

15 On Keynes's elitism, see Buchanan and Wagner (1977: 80), Cristiano (2014: 24, 63, 136), Davenport-Hines (2015: 258, 303), Dostaler (1996: 21; 2007: 89, 99, 102, 109), Fletcher (1987: 264), Friedman (1990: 86), Hession (1984: 219), Moggridge (1992: 452), O'Donnell (1989: 66), and Skidelsky (1983: 1, 118; 1992: 8, 224, 422 ; 2000: 474; 2009: 148). Keynes's elitism led him to advocate imperialism: «Keynes was an imperialist» (Cristiano 2014: 30,47). Cristiano argues that he is a liberal imperialist, but in fact he is a socialist-imperialist. Also, his elitism explains his sexist and racist inclinations (Dostaler 2007: 85; Harcourt and Turnell 2005: 493; Moggridge 1992: 183; Skidelsky 1983: 129; Toye 2000: 151-4). Finally, Keynes's elitism is reflected in his passionate support of government enforced population control and eugenics (Hernandez and Magness 2017; Meltzer 1988: 13, 38; O’Donnell 1992: 779-80; Raico 2008: 172).

16 Paul Levy's description of Keynes's lover Lytton Strachey as a «champagne socialist» also applies to Keynes (Levy in Strachey 2005: vii, 556). Generally, Keynes's Bloomsbury friends were elitist, champagne socialists (Marler in Bell 1993: xviii; Rosenbaum 2003: 85, 145; Rosner 2014: 13). Keynes was a financial patron and frequent resident of the Bloomsbury commune, Charleston House (Skidelsky 1992: 13-4). Before 1925, Keynes often brought his lover Sebastian Sprott, a «committed socialist», to the 
Keynes wanted socialism to replace capitalism, but he rejected Marxian tactics. While Marx wanted socialism to be introduced by violent class revolution, Keynes advocated the gradual implementation of socialism: «socialisation can be introduced gradually and without a break in the general traditions of society» (CW 7: 378). He rejected Marx's revolutionary approach: «I do not believe that there is any economic improvement for which revolution is a necessary instrument. On the other hand, we have everything to lose by the methods of violent change. In Western industrial conditions the tactics of Red Revolution would throw the whole population into a pit of poverty and death» (CW 9: 267). Keynes and Marx wanted to achieve the same goals, but Keynes recommended the gradual introduction of socialism because he thought that violent, revolutionary implementation would undermine the socialist experiment: «The economic transition of a society is a thing to be accomplished slowly... We have a fearful example in Russia today of the evils of insane and unnecessary haste... A rapid transition will involve so much pure destruction of wealth that the new state of affairs will be, at first, far worse than the old, and the grand experiment will be discredited» (CW 21: 245). Keynes was not a revolutionary socialist; he was a socialist of the chair (Kathedersozialist).$^{17}$

Keynes's vision and Marx's vision are remarkably similar, but Keynes was not a Marxist. This has led many interpreters to conclude that Keynes was not a socialist. However, he did not believe that socialism meant Marxism or government ownership of the means of production. He acknowledged different varieties, or types of socialism. In the General Theory he recognizes «an anti-Marxian socialism», and after the General Theory was published he distinguished «Marxism... from other systems of socialism»

Charleston commune (Mackrell 2009: 332). Also, Keynes's wife Lydia Lopokova advocated a form of elitist socialism (Mackrell 2009: 259, 281).

17 In 1949, Ludwig von Mises, the twentieth century's harshest critic of socialism, aligned Keynes with the German katheder socialists: «Keynes was influenced by the German socialists of the chair and ... he outdid them in many points» (Mises quoted in Hulsmann 2007: 881). Keynes's system of socialism is strikingly similar to the German system of socialism (Zwangswirtschaft) in which the uncertainty bearing entrepreneurs are transformed into shop managers (Betriebsfuhrer). See Mises (1922: 485; 1944: 66, 230; 1949: 713; 1952: 45, 55, 115; 1990: 176, 243). 
(CW 7: 355; CW 28: 334). Thus, Keynes's rejection of Marxian socialism or Labor Party tactics does not mean that he rejected all forms of socialism:

As every serious student knows, diverse doctrines of socialism have been propounded over the last two centuries by Babeuf, Blanc, Cabet, Fourier, Lasalle, Marx, Morris, Owen, Saint-Simon and Sismondi, to name but a few.... Marx (1847) himself acknowledged plurality within the socialist tradition.... the Communist Manifesto recognised seven additional forms of socialism ... It is a central weakness of the traditional account of Keynes's politics that it does not distinguish between different forms of socialism, and thus slips into massive conflation. It presupposes that whenever Keynes criticised or opposed a particular type of socialism [Marxism or the Labour Party] he was therefore reacting against socialism in general.... opposition to certain types of socialism does not imply blanket opposition to all types (O'Donnell 1999: 151)

Rather than showing that he rejected socialism, Keynes's attack on Marx illustrates that «Each socialist coterie is fanatically opposed to the plans of all other socialist groups» and «every socialist wants his own socialism, not the other fellow's» (Mises 1922: 566; 1944: 242-3). Like all socialists he had his own brand of socialism, sometimes called liberal-socialism (Moggridge 1992: 469; Groenewegen 1995: 153; Dostaler 2007: 98). However, classical liberals can argue that, etymologically, the term liberal-socialism is problematic; it is a contradictio in adjecto. ${ }^{18}$ Instead, Keynes is best described as a non-Marxist socialist (Fitzgibbons 1988: 191; O'Donnell 1992: 781-2; Darity 1995: 39). Still, Keynes's non-Marxist socialism is a legitimate, genuine form of socialism. In summary, Keynes was a socialist from 1907 until his death in 1946.

\footnotetext{
${ }^{18}$ Keynes is often aligned with a «middle way» which aims to combine the best features of capitalism and socialism while avoiding each system's alleged flaws. However, for a classical liberal there is no middle way between socialism and capitalism. Tertium non datur: «either private property in the means of production is allowed to function freely, or control over the means of production is transferred to organized society, to its apparatus of coercion, the state... there can be no alternative but socialism or capitalism» (Mises 1929: 52). On the middle way, see Mises (1922: 496-7; 1927: 50-8; 1929: 26, 38, 86; 1944: 74; 1949: 857; 1952: 41-52; 1990: 63-4).
} 


\section{$\mathrm{V}$ \\ KEYNES AND THE IS-LM MODEL}

Keynes wrote the General Theory to rationalize non-Marxist socialism. The IS-LM model is the standard interpretation of the General Theory, but some interpreters reject the IS-LM interpretation: «Hicks's IS-LM version of Neoclassical Keynesianism, was not representative of Keynes's general theory framework» (Davidson 2007: 176). The basis for rejecting the IS-LM interpretation is the traditional view that John R. Hicks invented the IS-LM model. Interpreters who reject IS-LM argue that Hicks misrepresented the General Theory: «Keynes's Vision is surely quite different than Hicks's generalisation... Keynes never liked the general equilibrium method... Hicks's generalisation is not something Keynes would have done himself» (Skidelsky 1992: 615). More detailed accounts list David G. Champernowne (1936), W. Brian Reddaway (1936), Roy Harrod (1937), James Meade (1937), John R. Hicks (1937), and Oskar Lange (1938) as co-inventors of IS-LM. Still, it is widely believed that Keynes did not invent the IS-LM model. To fully understand Keynes's politics and economics it is absolutely essential to look at the early development of the IS-LM model.

Notes taken during Keynes's lectures reveal that Keynes invented the IS-LM model in 1933. By mid-1933 Keynes had developed the theory of effective demand, the liquidity preference theory of interest, and the notion of the marginal efficiency of capital (Moggridge 1992: 564-5). Student notes from Keynes's lectures show that Keynes presented the first four-equation IS-LM model on 4 December 1933 in a lecture at Cambridge (1988: B58, E15, G34, J37, M19, N17). Also, the mid-1934 draft of the General Theory contains the IS-LM model (CW 13: 439-42, 483-4). Thus, the IS-LM model was presented for the first time by Keynes in his fall 1933 lectures and in the mid-1934 draft of The General Theory. In short, the IS-LM model was invented by Keynes. ${ }^{19}$

${ }^{19}$ For more on Keynes's lectures see Dimand (2007: 85-7; 2014: 17), Fuller (2017), Moggridge (1992: 556), Patinkin (1976: 79n22; 1977: 16; 1982: 23), Solow (1991), Skidelsky (1992: 496), and Young (1987: 13, 33, 54). On the mid-1934 draft see Fuller (2017), Meltzer (1988: 143), Patinkin (1976: 75-9), and Young (1987: 13). Patinkin observes, «to judge 
There is no formal version of the IS-LM model in the General Theory, and this has led some interpreters to doubt the IS-LM interpretation. Still, all of the elements of the IS-LM model are in the General Theory. The four elements of the IS-LM model are the consumption function (CW 7: 90), the investment demand function (CW 7: 135-7), the liquidity preference function (CW 7: 199), and the money supply (CW 7: 247). The elements of the IS-LM model are scattered throughout the General Theory and he never brought all the elements together in a formal manner. However, Keynes (CW 7: 246-7) gives an informal statement of the IS-LM model and suggests how the elements of his theory can be combined: «if we have all the facts before us, we shall have enough simultaneous equations to give us a determinate result» (CW 7: 299)..$^{20}$ The General Theory does not contain a formal statement of the IS-LM model, but «an informal version of the model was there to be found» (Laidler 1999: 4). ${ }^{21}$ The IS-LM model is in the General Theory.

The earliest IS-LM papers emerged out of Keynes's lectures and tutoring. David G. Champernowne and W. Brian Reddaway published the first IS-LM papers. Champernowne and Reddaway were

from the subsequent rapid acceptance of the... IS-LM model as the standard representation of the General Theory - the revealed preference of the profession is actually for the more formal style of presentation of the analysis that Keynes used in his 1934 draft» (1976: 76).

${ }^{20}$ Keynes advocates the simultaneous equations approach in his lectures and in early drafts of the General Theory (1988: A38, A43, G14; I21; 1989: 76-77, 110; CW 13: 403, 405; CW 14: 478; CW 29: 65, 98). Meltzer notes that Keynes used the simultaneous equations approach in A Treatise on Money and, thus, the «analysis of the Treatise introduces the key ideas that became familiar as the IS-LM model» (1988: 111-2, 17, 75, 77, 97, 109, 196).

${ }^{21}$ Many scholars agree that the General Theory contains an informal version of ISLM, including Backhouse and Bateman (2011b: 12), Barens (1999: 86, 97), Hansen (1953: 147), Harcourt and Turnell (2005: 4939-40), Jackman (1974: 8), Meltzer (1988: 170, 258; 1992: 160), and Patinkin (1982: 12; 1990: 212). There is no formal version of IS-LM in the General Theory because, following Alfred Marshall, «Keynes used mathematics as a shorthand language but published only a translation into English without the mathematics» (Dimand 2007: 90). However, Hansen (1932; 1953: 32, 140-8) and Naylor (1968) show that Keynes did not always correctly move between mathematics and English. «He was not a remarkable mathematician» (Skidelsky 1992: 432). Keynes did not include a formal version of IS-LM in the General Theory because he did not realize that his English translation of the pure liquidity preference theory is mathematically indeterminate (Hansen 1953: 140-8; Laidler 1999: 282; Presley 1979: 186-7). 
undergraduate students at Cambridge, and both attended Keynes's 4 December 1933 IS-LM lecture. Keynes was their supervisor (or tutor) at Cambridge where «Most of the serious teaching was done by supervision» (Johnson and Johnson 1978: 88). Additionally, they were members of the Political Economy Club which Keynes used to influence his disciples. Keynes and Champernowne were Cambridge Apostles, and Keynes started the Social Work Committee with Reddaway's father in 1903. Champernowne submitted his paper to The Review of Economic Studies before publication of the General Theory, and he admits that his IS-LM paper "was based on Keynes' lectures and supervisions» (quoted in Young 1987: 83). After seeing Reddaway's IS-LM paper Keynes replied, «I enjoyed your review of my book in the Economic Record, and thought it very well done» (CW 14: 70). The earliest published IS-LM papers were written by students who collaborated directly with Keynes and their IS-LM papers would have been unimaginable without him.

Roy Harrod was the author of the third IS-LM paper. Harrod was Keynes's close friend and colleague, and he had a significant impact on the General Theory. Harrod received proofs of the General Theory in early June 1935 and his IS-LM paper resulted from his discussions with Keynes later that summer. By 14 September Keynes and Harrod co-created the only diagram in the General Theory, and that diagram is equivalent to the IS curve (CW 13: 557). After reading Harrod's IS-LM paper Keynes wrote, «I like your paper (may I keep the copy you have sent me?) more than I can say. I have found it instructive and illuminating, I really have no criticisms. I think that you have re-orientated the argument beautifully» (CW 14: 84). He told Dennis Robertson that «Roy has written for the Econometric Meeting at Oxford an elucidation of my book which I think extraordinarily good» (CW 14: 88). Harrod's IS-LM paper resulted from direct collaboration with Keynes and he accepted Harrod's interpretation.

James Meade, the self-proclaimed «liberal-socialist», wrote the fourth IS-LM paper. Meade was a core member of the Cambridge Circus, the Political Economy Club, and the General Theory group. ${ }^{22}$ In a Fabian Society pamphlet Meade (1933) made an essen-

${ }^{22}$ Like Keynes, all the members of the General Theory group were associated with a socialist organization called the New Fabian Research Bureau: «Members of the 
tial contribution to Keynesian theory by incorporating saving into the multiplier. Meade read Harrod's IS-LM paper before he started writing his own paper and, although he used different notation, his model is identical to the IS-LM model presented by Harrod and Hicks. Keynes told Meade, «Thanks for the copy of your paper. It's excellent. I have no criticisms to suggest... it was a true representation of the General Theory» (quoted in Young 1987: 37). Keynes's comments on Meade's IS-LM paper show that he accepted IS-LM.

It is a myth that John R. Hicks invented the IS-LM model. Keynes invented the IS-LM model in 1933, and Champernowne, Reddaway, Harrod, and Meade wrote their IS-LM papers before Hicks. Hicks read the IS-LM papers by Champernowne, Harrod, and Meade before he started writing his paper, but «Hicks's failure to acknowledge both Harrod's and Meade's papers in his own, gave the initial impression that he discovered the IS-LM approach independently and alone» (Young 1987: 171). Although Hicks's paper is most famous because it introduced the IS-LM diagram, that diagram is his only contribution to the development of IS-LM. Nonetheless, Keynes endorsed Hicks's IS-LM interpretation: «I found it very interesting and really have next to nothing to say by way of criticism» (CW 14: 79). Hicks confirms that «Keynes accepted the ISLM diagram as a fair statement of his position» (1977: 146). Hicks did not invent IS-LM, but Keynes accepted his General Theory IS-LM model.

In 1938 Keynes endorsed the IS-LM paper by the Marxian socialist Oskar Lange. Keynes's endorsement of Lange's IS-LM paper

\footnotetext{
New Fabian Research Bureau, set up in 1931 by [socialists] G.D.H. Cole and Hugh Dalton, included, as well as Gaitskell and Durbin, such friends of Keynes as Colin Clark, Roy Harrod, Richard Kahn, James Meade, Joan Robinson and Leonard Woolf» (Dostaler 2007: 117; Clarke 1988: 286). The New Fabian Research Bureau was the research arm of the Society for Socialist Inquiry and Propaganda, and they shared the same Secretary and office (Cole 1948: 282-3; Cole 1961: 225-31). The New Fabian Research Bureau and the Fabian Society amalgamated in 1938, and Beatrice Webb remained president until 1941 (Pugh 1984: 179-80). Like Keynes, «The [Fabian] Society sought to establish a non-Marxist socialism to be arrived at through gradual transformation rather than violent revolution» (Dostaler 2007: 106). Reddaway later became a representative of the Fabian Society. Champernowne went beyond the liberal-socialism of Meade toward the radical socialism of Joan Robinson. On Keynes's disciples, see Cord (2012: 45-55), Harcourt (2012), and Robinson (1977).
} 
is important because it appeared in print sixteen months after the publication of Keynes's celebrated 1937 article in the Quarterly Journal of Economics. In the Economic Journal Keynes wrote, «The analysis which I gave in my General Theory of Employment is the same as the «general theory» explained by Dr. Lange» (CW 14: 232n1; Moggridge 2002: 641). At the beginning of his paper Lange acknowledges that his system of IS-LM equations is similar to Reddaway's, Harrod's, and Hicks's (1938: 12n1). Thus, Keynes's direct endorsement of Lange's IS-LM interpretation is a late, albeit indirect, endorsement of the IS-LM papers by Reddaway, Harrod, and Hicks.

Some interpreters still reject the IS-LM interpretation despite the fact that Keynes gave consistent approval of the IS-LM model. Interpreters who reject the IS-LM interpretation of the General Theory cannot cite Keynes to support their view. He had a decade to reject the IS-LM model, but he never rejected the IS-LM interpretation: «Keynes never once repudiated the IS-LM interpretation of the General Theory. On the contrary, he endorsed it warmly» (King 2002: 31). Keynes invented the IS-LM model, the IS-LM model is in the General Theory, Keynes was the key collaborator with the authors of the early IS-LM papers, and Keynes accepted the IS-LM interpretation after the General Theory was published. The IS-LM model is the correct interpretation of Keynes's General Theory.

VI

\section{KEYNES'S ECONOMIC JUSTIFICATION FOR NON-MARXIST SOCIALISM}

Keynes invented the IS-LM model to justify non-Marxist socialism. Just weeks before he presented the IS-LM model for the first time, Keynes admitted that the «form and substance» of his theory had changed, but «The underlying ideas [are] still very much the same» (1988: B1, emphasis added). Keynes's ideas are usually illustrated with Hick's IS-LM diagram, but Hicks did not design the IS-LM diagram specifically to illustrate Keynes's economic theory. He designed the IS-LM diagram to compare the Keynesian framework 
with the Classical framework (Hicks 1937: 148). ${ }^{23}$ Keynes's economic justification for non-Marxist socialism is better illustrated by using the IS-LM equations to graph the relationship between consumption and investment. In the IS-LM model, equation 1 is the amount of consumption and equation 2 is the amount of investment. $^{24}$

$$
\begin{aligned}
& \text { Consumption }=\frac{a(n k+h)+b(d h+n M)}{h(1-b)+n k} \\
& \text { Investment }=\frac{(1-b)(d h+n M)-a n k}{h(1-b)+n k}
\end{aligned}
$$

In figure 1, the vertical axis shows the amount of consumption and the horizontal axis shows the amount of investment. Equation 1 and equation 2 are used to derive the Consumption-Investment (CI) curve. The CI curve is derived by plotting the amount of consumption and the amount of investment at different levels of autonomous investment $(d)$. The CI curve summarizes the relationship between consumption and investment in Keynes's theory.

${ }^{23}$ The IS-LM diagram is often used to illustrate the Classical theory with a vertical LM curve, but Keynes admitted that his theory is incompatible with the Classical theory (CW 14: 79). See Backhouse and Laidler (2004), Coddington (1983: 69-70), and Laidler (1999: 309) for more on the incompatibility of IS-LM and the Classical theory. The IS-LM model cannot accurately depict the pre-Keynesian theory because Keynes' theory rules out forced saving. On forced saving see Garrison (2004), Hayek (1931: 243, 309), Huerta de Soto (1998: 409-13), Laidler (1999: 38, 89-96), Mises (1949: 545-62), Presley $(1979: 74,103,119,168)$, and Steele $(2007: 131-2,166)$.

${ }^{24} a$ is autonomous consumption, $b$ is the marginal propensity to consume, $d$ is autonomous investment, $n$ is the interest sensitivity of investment, $k$ is the sensitivity of money demand to income, $h$ is the sensitivity of money demand to the interest rate, and $M$ is the real money supply. Keynes's main concern is autonomous investment $(d)$. 
FIGURE 1

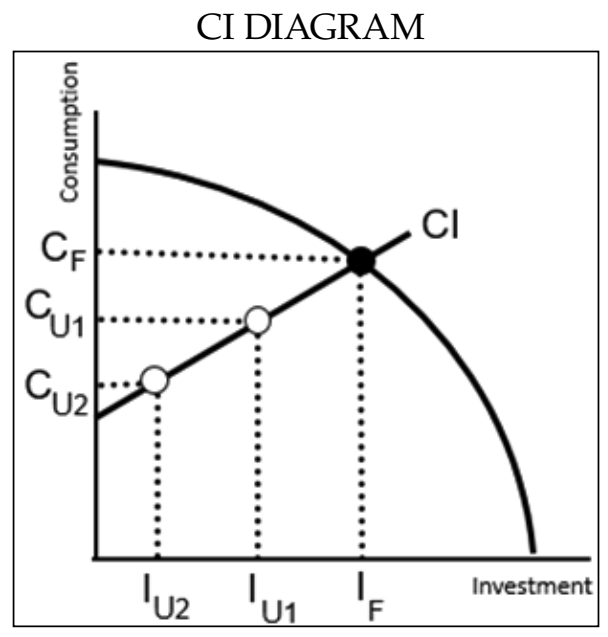

The CI curve has two important properties. First, the CI curve is upward sloping. This means that the amount of consumption and investment always move in the same direction in Keynes's theory. He argued that output and investment are positively related before he invented the IS-LM model. On 2 May 1932 he said, «the volume of employment depends on the amount of investment, and anything which increases or decreases the latter will increase or decrease the former» $(1989: 31) .{ }^{25}$ Since the amount of consumption and investment move in the same direction, the economy cannot move along the production frontier. Keynes's theory «holds not that C and I are alternatives but rather they move together» (1988: L9). Therefore, there is no trade-off between the amount of consumption and investment in the Keynesian theory. Second, the

${ }^{25}$ Also see Keynes (1988: A10, A47, B41, E9, G18, G20, H25, I26, J24, J27, K16, O20). The positive relationship between the amount of consumption and investment is essential to Keynes's theory. In the Classical theory there is a trade-off between the amount of consumption and investment; they can move in opposite directions. When the General Theory was published, «The proposition that a change in [investment] spending will cause output to change in the same, rather than the opposite, direction was then controversial» (Dimand 1988: 151). Meltzer (1988: 153), Dimand (1988: 189), and especially Garrison (2001: 136) stress the positive relationship between the amount of consumption and investment in Keynes's theory. 
point where the CI curve intersects the production possibilities frontier represents full-employment. Figure 1 shows that there is full employment at the level of full investment $\left(\mathrm{I}_{\mathrm{F}}\right)$. At less than full investment ( $\mathrm{I}_{\mathrm{U} 1}$ or $\left.\mathrm{I}_{\mathrm{U} 2}\right)$ there is unemployment. Unemployment exists when the economy is located inside the production frontier. ${ }^{26}$

Keynes's theory is a theory of chronic economic stagnation. He argued that chronic stagnation is the essential feature of the free market economy many years prior to inventing the IS-LM model. During 1931, before work started on the General Theory, Dennis Roberson said, «Mr. Keynes's legend seems to be not so much one of cyclical depression as secular decay» (1931: 399n1). In his lectures Keynes told his audience, «The level of effective demand which leads to full employment is a special case, and there is no automatic reason why that level should always exist» (1988: H11). He argued that «there should be on the average a tendency to severe unemployment» (1988: L9). Mass unemployment is the normal condition of the market economy for Keynes. In figure 1, the chronic stagnation thesis means that the economy is normally located inside the production frontier $\left(\mathrm{I}_{\mathrm{U} 1}\right){ }^{27}$

Investment is the driving force of the economy in Keynes's theory. On 19 November 1934 he declared, «Income cannot increase without an increase in Investment ... More Investment is a necessary condition of an increase in income» (1988: C33). Investment is the key variable in Keynes's theory, and he argued that chronically low investment is the fundamental problem with the free market

${ }^{26}$ Roger W. Garrison developed the Keynesian demand constraint diagram. Garrison (2001: 136) does not derive the demand constraint from the IS-LM model, but he notes that it is possible (1995: 130n2). Meltzer alludes to the demand constraint diagram $(1988: 118,153)$. See Fuller $(2015)$ and Garrison $(1995,2001,2005)$ for more on the demand constraint diagram.

${ }^{27}$ For more on Keynes's stagnation thesis, see Brunner (1996: 196), Clarke (1988: 326-7), Davenport-Hines (2015: 184), Davidson (2007: 79), Dillard (1948: 269), Dostaler (2007: 201), Garrison (1992: 137; 2001: 145, 168, 177), Fletcher (1987: 186), Johnson and Johnson (1978: 27, 204), Hayes (2006: 197, 201), Kahn (1984: 142), Klein (1949: 68), Laidler (1999: 265, 292), Lawlor (2006: 35, 243), Littleboy (1990: 93), Meltzer (1988: 6, 123, 153, 172, 300), Milgate (1982: 3, 84, 90), Moggridge (1973: 75), O'Donnell (1989: 242), Patinkin (1987: 29), Perelman (1989: 87-8), Sheehan (2010: 277), and Skidelsky (1992: 318, 462, 484, 545, 615; 2009: 97-9). 
economy: «The weakness of the inducement to invest has been at all times the key to the economic problem» (CW 7:347-8). ${ }^{28}$ In terms of equation 1 and equation 2, Keynes blamed economic stagnation on autonomous investment $(d)$. Full employment requires full investment, but chronic stagnation occurs because autonomous investment is chronically low. Figure 1 shows that the normal amount of investment $\left(\mathrm{I}_{\mathrm{U} 1}\right)$ is chronically lower than the amount of full investment $\left(\mathrm{I}_{\mathrm{F}}\right)$. Keynes's economic justification for non-Marxist socialism is ultimately based on his theory of investment.

The General Theory contains a business cycle theory, but it is not a book about the business cycle. In terms of equation 1 and equation 2 , the business cycle is caused by fluctuations of autonomous investment $(d)$. Autonomous investment collapses when there is a sudden collapse in the future cash flows investors expect to receive from investment projects: «Our [cash flow] expectations are very flimsily based, and therefore very susceptible to changes in atmosphere; as a result the marginal efficiency of capital is subject to very rapid fluctuation. This is the fundamental explanation of the violent changes associated with the trade cycle, and of the general instability of the economic system» (Keynes 1988: H29). In figure 1, the collapse in autonomous investment causes the amount of investment to fall from $\mathrm{I}_{\mathrm{U} 1}$ to $\mathrm{I}_{\mathrm{U} 2}$. The amount of consumption falls from $\mathrm{C}_{\mathrm{U} 1}$ to $\mathrm{C}_{\mathrm{U} 2}$ because «investment and consumption will run together» (Keynes 1988: L19). When autonomous investment collapses, the economy falls from a point inside the frontier to a point even deeper inside the frontier. The Keynesian stagnation thesis means that the business cycle occurs inside the production frontier. The General Theory is a book about chronic stagnation, and Keynes's business cycle theory is just an application of his stagnation thesis.

${ }^{28}$ Keynes thought that investment was the fundamental problem with the free market economy decades before he invented the IS-LM model: «Keynes's interest in the role of investment represented a constant factor in all his thought. Moreover, Keynes's attitude towards investment... remained substantially unchanged from his early articles written at the beginning of the century to the latest contributions written after The General Theory" (Carabelli 1988: 195). Four months before the A Treatise on Money was published he wrote, «the trouble is to be found - in my opinion with mathematical certainty - in an inadequate volume of total investment» (CW 20: 365). Also see Moggridge (1992: 373, 486), O’Donnell (1992: 775), and Skidelsky (1992: 184). 
Since the publication of the General Theory, the IS-LM model has served as the main justification for countercyclical fiscal and monetary policy. Keynes was an interventionist who supported all types of government intervention in the economy, but he did not strongly advocate countercyclical policy. He only grudgingly advocated public works as a second-rate solution because investment was not socialized. On 1 July 1931 he declared, «I am in favor of an admixture of public works, but my feeling is that unless you socialize the country to a degree that is unlikely, you get to the end of the public works program... you have shot your bolt, and you are no better off... I should be afraid of that as the sole remedy» (1931: 494). In 1943 he affirmed, "public works at short notice is a clumsy form of cure and not likely to be completely successful» (CW 27: 326). Although Keynes preferred public works to laissez-faire, he did not believe that public works or fiscal fine-tuning could abolish cyclical or secular unemployment.

Keynes recommended an artificially low interest rate, but he wanted the interest rate to be permanently low and stable. He did not want the short-term interest rate to be used to counteract the business cycle:

Anyone who is well acquainted with my writings will, however, be aware that I am not one of those who believe that the business cycle can be controlled solely by manipulation of the short-term rate of interest, that I am indeed a strong critic of this view... My proposals for the control of the business cycle are based on the control of investment (1933b: 675)

Similarly, he did not recommend manipulating the long-term interest rate to control the business cycle: «The long-term rate of interest must be kept continuously as near as possible to what we believe to be the long-term optimum. It is not suitable to be used as a short period weapon» (CW 21: 389). Generally, he thought that countercyclical monetary policy is «A clumsy instrument» (1988: H43). Although increasing the money supply can stimulate economic activity in Keynes's theory, «Effective demand will not increase in the same proportion as money» (1988: H41). Consequently, «There is no inherent tendency for [the] economic system to react back to the optimum output regardless of the monetary poli- 
cy followed — that is even when there is complete fluidity» (Keynes 1988: I19)..$^{29}$ An important purpose of the General Theory and IS-LM is to show that monetary policy alone cannot eliminate unemployment. Keynes did not believe that countercyclical fiscal or monetary policy could cure unemployment and he did not invent the IS-LM model to rationalize countercyclical policy.

Keynes's main policy recommendation is socializing investment. As a consequence of his stagnation thesis, his primary policy goal was curing chronic, not cyclical, unemployment: «the study of the investment programme should be a study of structural unemployment» (CW 27: 357). As Keynes saw it, «the only solution is for long-term investment to be controlled by the State» (1989: 154, emphasis added). In terms of equations 1 and 2, socializing investment gives the government the power to increase autonomous investment $(d)$ until the amount of investment reaches full investment. In figure 1, the government increases autonomous investment so that the amount of investment rises from $\mathrm{I}_{\mathrm{U} 2}$ to $\mathrm{I}_{\mathrm{F}}$. Increased autonomous investment causes the amount of consumption to rise from $\mathrm{C}_{\mathrm{U} 2}$ to $\mathrm{C}_{\mathrm{F}}$. Socializing investment allows the government to push the economy up the CI curve to the point of full employment on the production frontier. Moreover, Keynes argued that the government should keep the economy on the frontier permanently. For Keynes, «the State would fill the vacant post of entrepreneur-in-chief» and maintain «the general average of industrial production and activity at the optimum level» (CW 27: 324; CW 21: 90). Thus, his program of socializing investment is a permanent

${ }^{29}$ Some economists argue that wages and prices are fixed in Keynes's theory, but this view is incomplete. In chapter 19 of the General Theory Keynes argues that «a flexible wage policy and a flexible money policy come, analytically, to the same thing» (CW 7: 262). For more on wages and prices in Keynes's theory, see Clarke (1988: 280; 2009: 15), Davidson (2007: 40), Dillard (1948: 25), Hansen (1953: 173), Harrod (1946: 180), Kahn (1984: 128), Laidler (1999: 332), Lawlor (2006: 27), Leijonhufvud (1968: 161), Littleboy (1990: 93-4), Meltzer (1988: 164, 259), Milgate (1982: 104, 106), Robinson (1971: 90), Mini (1991: 182-4), Moggridge (1976: 92), O’Donnell (1989: 176), Patinkin (1976: 1012; 1982: 138), and Skidelsky (1992: 463, 567; 2009, 96). On the liquidity trap, see Clarke (1988: 324), Davidson (2007: 174, 191n1), Fitzgibbons (1988: 159n3), Fletcher (1987: 128), Hayes (2006, 48), Klein (1949: 72), Laidler (1999: 258), Leijonhufvud (1968: 161), Littleboy (1990: 189), Meltzer (1988: 279), Milgate (1982: 186), Patinkin (1976: 114), Presley (1979: 199), Sheehan (2009: 236), and Skidelsky (1992: 464). 
program: «In good time we can do it all. But we must work to a long-term programme... With a big [investment] programme carried out at a properly regulated pace we can hope to keep employment good for many years to come. We shall, in very fact, have built our New Jerusalem out of the labour which in our former vain folly we were keeping unused and unhappy in enforced idleness» (CW 27: 269-70). Keynes invented the IS-LM model to show that his brand of non-Marxist socialism is the only way to permanently cure the business cycle and chronic economic stagnation.

\section{VII CONCLUSION}

John Maynard Keynes's IS-LM model is the most influential theory in the history of macroeconomics. James Tobin and Robert Solow describe the IS-LM model as the «trained intuition» of economists (1996: 24; 1984: 14). As the profession's trained intuition, the IS-LM model has exercised a powerful influence over economists and, through them, the events in history. Those economists who operate with IS-LM as their trained intuition uncritically accept that Keynes's model is «a tool of scientific research» (Samuelson 1990; Friedman 1990: 89; Patinkin 1988: 5453). However, Keynes was not a value-free economic scientist and the IS-LM model was not invented as a tool of scientific research: «Keynes did not believe that economics should be neutral» and «The economic theory he developed, known more appropriately as political economy, was subordinate to politics» (Fitzgibbons 1988: 43; Dostaler 2007: 80). The central thesis of this paper is that Keynes invented the IS-LM model to provide an intellectual justification for non-Marxist socialism. In other words, the IS-LM model is a political tool invented to justify the systematic violation of private property rights by government. Keynes's economic justification for non-Marxist socialism will continue exercising a powerful influence over the events in history until economists and policy makers retrain their intuition. 


\section{BIBLIOGRAPHICAL REFERENCES}

Alchian, Armen A. (1955). The Rate of Interest, Fisher's Rate of Return over Cost and Keynes' Internal Rate of Return. American Economic Review 45: 938-942.

BackHouse, R.E., and B.W. BAteman. (2008). Keynes, John Maynard (new perspectives). In Durlauf and Blume (Eds.), The New Palgrave Dictionary of Economics. New York: Palgrave Macmillan: 716-25.

- (2010). Whose Keynes? In Dimand, Mundell and Vercelli (Eds.), Keynes's General Theory After Seventy Years. New York: Palgrave Macmillan: 8-27.

- (2011a). Capitalist Revolutionary: John Maynard Keynes. Cambridge, M.A.: Harvard University Press.

- (2011b). On Post Keynesian Economics and the Economics of Keynes. Unpublished Manuscript.

BACKHOuse, R.E., and D. LAIDLER. (2004). What Was Lost with IS-LM. Annual Supplement to History of Political Economy, 36: 25-56.

BARENS, I. (1999). From Keynes to Hicks-An Aberration? IS-LM and the analytical nucleus of the General Theory. In Howitt, de Antoni, and Leijonhufvud (Eds.), Money, Markets, and Method: Essays in Honour of Robert W. Clower. Cheltenham, U.K.: Edward Elgar: 85-120.

BARnETT, V. (2013). John Maynard Keynes. London: Routledge.

Bateman, B.W. (1988). G. E. Moore and J. M. Keynes: A Missing Chapter in the History of the Expected Utility Model. The American Economic Review, 78 (5): 1098-1106.

Bell, V. (1993). Selected Letters of Vanessa Bell. New York: Pantheon Books.

BOHM-BAWERK, E.V. (1890). Capital and Interest. London: Macmillan. BRunNer, K. (1996). Economic Analysis and Political Ideology. Brookfield: Edward Elgar.

Buchanan, J.M., and Wagner, R.E. (1977). Democracy in Deficit: The Political Legacy of Lord Keynes. Indianapolis: Liberty Fund, 2000. Carabelli, A.M. (1988). On Keynes's Method. New York: Macmillan. Champernowne, D.G. (1936). Unemployment, Basic and Monetary: The Classical Analysis and the Keynesian. The Review of Economic Studies 3 (3): 201-16. 
Clarke, P.F. (1983). The Politics of Keynesian Economics, 1924-1931. In Bentley and Stevenson (Eds.), High and Low Politics in Modern Britain. Oxford: Clarendon Press Oxford University Press: 15481.

- (1988). The Keynesian Revolution in the Making, 1924-1936. New York: Oxford University Press.

- (1996). The Historical Keynes and the History of Keynesianism. In Blanning and Cannadine (Eds.), History and Biography: Essays in Honour of Derek Beales. New York: Cambridge University Press: 203-26.

- (1998). The Keynesian Revolution and Its Economic Consequences: Selected Essays. Northampton, M.A.: Edward Elgar.

- (2009). Keynes: The Rise, Fall, and Return of the 20th Century's Most Influential Economist. New York: Bloomsbury Press.

Coddington, A. (1983). Keynesian Economics: The Search for First Principles. London: Allen \& Unwin.

Cole, G.D.H. (1948). A History of the Labour Party from 1914. London: Routledge \& Kegan Paul LTD.

- (1950). Socialist Economics. London: Victor Gollancz.

Cole, M. (1961). The Story of Fabian Socialism. Stanford, Calif.: Stanford University Press.

CoRD, R. (2012). Reinterpreting the Keynesian Revolution. New York: Routledge.

Cranston, M. (1978). Keynes: His Political Ideas and Their Influence. In Thirlwall (Ed.), Keynes and Laissez-Faire. London: Macmillan: 101-15.

Cristiano, C. (2014). The Political and Economic Thought of the Young Keynes. New York: Routledge.

Dalton, H.D. (1986). The Political Diary of Hugh Dalton, 1918-1940, 1945-60. Pimlott (Ed.). London: J. Cape.

DARITY, W.A. (1995). Keynes' Political Philosophy: The Gesell Connection. Eastern Economic Journal, 21 (1): 27-41.

Davenport-Hines, R. (2015). Universal Man: The Lives of John Maynard Keynes. New York: Basic Books.

Davidson, P. (2007). John Maynard Keynes. New York: Palgrave Macmillan.

DAvis, J.B. (1994). Keynes's Philosophical Development. Cambridge: Cambridge University Press. 
Dillard, D. (1942). Keynes and Proudhon. The Journal of Economic History, 2 (1): 63-76.

- (1948). Economics of John Maynard Keynes. Englewood Cliffs, N.J.: Prentice-Hall.

- (1984). Keynes and Marx: A Centennial Appraisal. Journal of Post Keynesian Economics, 6 (3): 421-32.

Dimand, R.W. (1988). The Origins of the Keynesian Revolution. Stanford, Calif.: Stanford University Press.

- (2007). Keynes, IS-LM, and the Marshallian Tradition. History of Political Economy, 39 (1): 81-95.

-(2014). James Tobin. New York: Palgrave Macmillan.

Dostaler, G. (1996). The Formation of Keynes's Vision. History of Economics Review, 25: 14-31.

- (1999). Keynes and Economics: The Early Stage. Working Paper No. 9901. Université du Québec à Montréal.

- (2007). Keynes and His Battles. Cheltenham, U.K.: Edward Elgar.

- (2012). The General Theory, Marx, Marxism and the Soviet Union. In Cate (Ed.), Keynes's General Theory: Seventy-Five Years Later. Cheltenham, U.K.: Edward Elgar: 238-63.

EsHAG, E. (1963). From Keynes to Marshall. Oxford: Blackwell.

FAN-Hung. (1939). Keynes and Marx on the Theory of Capital Accumulation, Money and Interest. The Review of Economic Studies, 7 (1): 28-41.

Felix, D. (1995). Marx and Keynes: The Primacy of Politics. Biography, 18 (3): 219-27.

Fitzgibbons, A. (1988). Keynes's Vision: A New Political Economy. Oxford: Clarendon Press.

Fletcher, G.A. (1987). The Keynesian Revolution and its Critics. London: Macmillan.

- (2008). Dennis Robertson. New York: Palgrave Macmillan.

Friedman, B.M. (2008). Economic Well-being in a Historical Context. In Pecchi and Piga (Eds.) Revisiting Keynes: Economic Possibilities for our Grandchildren. Cambridge, M.A.: MIT Press: 12534.

Friedman, M. (1953). Essays in Positive Economics. Chicago: University of Chicago Press.

— (1997). John Maynard Keynes. Economic Quarterly, 83 (2): 1-23. 
- (1990). Milton Friedman. In Blaug (Ed.), John Maynard Keynes: Life, Ideas, Legacy. New York: St. Martin's Press: 81-89.

— and Friedman, R.D. (1990). Free to Choose: A Personal Statement. San Diego, Calif.: Harcourt.

FulLeR, E.W. (2013). The Marginal Efficiency of Capital. The Quarterly Journal of Austrian Economics, 16 (4): 379-400.

- (2015). Garrison on Keynes. The Quarterly Journal of Austrian Economics, 18 (1): 3-21.

- (2017). IYLM: A Comment. Cambridge Journal of Economics, forthcoming.

Galbraith, J.K. (1987). Keynes, Roosevelt, and the Complementary Revolutions. Challenge, 30 (6): 19-23.

GARRISON, R.W. (1992). Is Milton Friedman a Keynesian? In Skousen (Ed.), Dissent on Keynes: A Critical Appraisal of Keynesian Economics. New York: Praeger: 131-47.

- (1993). Keynesian Splenetics: From Social Philosophy to Macroeconomics. Critical Review, 6 (4): 471-92.

- (1995). Linking the Keynesian Cross and the Production Possibilities Frontier. The Journal of Economic Education, 26 (2): 122-30.

- (2001). Time and Money: The Macroeconomics of Capital Structure. New York: Routledge.

- (2004). Overconsumption and Forced Saving in the Mises-Hayek Theory of the Business Cycle. History of Political Economy, 36 (2): 323-49.

- (2005). The Austrian School. In Snowden and Vane (Eds.), Modern Macroeconomics: Its Origins, Development and Current State. Cheltenham, U.K.: Edward Elgar: 474-516.

Grant, D. (1926). Duncan Grant to Vanessa Bell, 16 April. Tate Archive, TGA 8010/5/1375/DGVB245(3). London: Tate.

GERRARD, B. (1997). Method and Methodology in Keynes's General Theory. In Harcourt and Riach (Eds.), A «Second Edition» of the General Theory Vol. 2. London: Routledge: 166-202.

Groenewegen, P. (1995). Keynes and Marshall: Methodology, Society, and Politics. Annual Supplement to History of Political Econo$m y, 27:$ 129-55.

Hansen, A.H. (1932). A Fundamental Error in Keynes's 'Treatise on Money'. The American Economic Review, 22 (3): 462. 
- (1936). Mr. Keynes on Underemployment Equilibrium. Journal of Political Economy, 44 (5): 667-86.

- (1953). A Guide to Keynes. New York: McGraw-Hill.

Harcourt, G.C. (2012). Keynes and his Cambridge Pupils and Colleagues. Meiji Journal of Political Science and Economics, 1: 12-25.

Harcourt, G.C., and P. Kerr. (2009). Joan Robinson. New York: Palgrave Macmillan.

Harcourt, G.C. and S. Turnell. (2005). Skidelsky's Keynes. Economic and Political Weekly, 40 (47): 4931-46.

HarroD, R.F. (1937). Mr. Keynes and Traditional Theory. Econometrica, 5 (1): 74-86.

- (1946). John Maynard Keynes. The Review of Economics and Statistics, 28 (4): 178-82.

- (1951). The Life of John Maynard Keynes. London: Macmillan.

Hayek, F.A. (1931). Prices and Production and Other Works. Auburn, Ala.: Ludwig von Mises Institute.

- (1948). Individualism and the Economic Order. Chicago: University of Chicago Press.

- (1960). The Collected Works of F.A. Hayek, Vol. 17: The Constitution of Liberty. Chicago: University of Chicago Press, 2011.

- (1979). Law, Legislation, and Liberty, Vol. 3: The Political Order of a Free People. New York: Routledge, 1998.

HAYEs, M. (2006). The Economics of Keynes: A New Guide to The General Theory. Cheltenham, U.K.: Edward Elgar.

Hession, C.H. (1984). John Maynard Keynes: A Personal Biography of the Man Who Revolutionized Capitalism and the Way We Live. London: Macmillan.

Hernandez, S.J., and Magness, P.W. (2017). The Economic Eugenicism of John Maynard Keynes. Journal of Markets and Morality, forthcoming.

HiCKS, J.R. (1937). Mr. Keynes and the «Classics»; A Suggested Interpretation. Econometrica, 5 (2): 147-59.

- (1977). Economic Perspectives: Further Essays on Money and Growth. Oxford: Clarendon Press.

Holland, S. (1977). Keynes and the Socialists. In Skidelsky (Ed.), The End of the Keynesian Era. New York: Holmes \& Meier Publishers: 67-77. 
Holroyd, M. (1994). Lytton Strachey. New York: W.W. Norton \& Company, 2005.

Huerta de Soto, J. (1998). Money, Bank Credit, and Economic Cycles. Auburn, A.L.: Ludwig von Mises Institute, 2006.

- (2010). Socialism, Economic Calculation and Entrepreneurship. Northampton, M.A.: Edward Elgar.

Hulsmann, J.G. (2007). Mises: The Last Knight of Liberalism. Auburn, A.L.: Ludwig von Mises Institute.

Hyams, E. (1963). The New Statesman: The History of the Fifty Years, 1913-1963. London: Longmans.

- (1974). The Millennium Postponed: Socialism from Sir Thomas More to Mao Tse-Tung. London: Secker \& Warburg.

Jackman. R. (1974). Keynes and Leijonhufvud. Oxford Economic Papers, 26 (2): 259-72.

JoHnson, E.S., and H.G. JoHnson. (1978). The Shadow of Keynes: Understanding Keynes, Cambridge, and Keynesian Economics. Chicago: University of Chicago Press.

KAHN, R.F. (1984). The Making of Keynes' General Theory. Cambridge: Cambridge University Press.

Keynes, J.M. (1904). Cambridge Union Notes, 16 February. The John Maynard Keynes Papers, OC/6/17. Cambridge, U.K.: King's College.

- (1906). John Maynard Keynes to Lytton Strachey, 23 January. The John Maynard Keynes Papers, PP/45/316/2/51. Cambridge, U.K.: King's College.

- (1907). John Maynard Keynes to Lytton Strachey, 25 October. The John Maynard Keynes Papers, PP/316/3/151. Cambridge, U.K.: King's College.

- (1911). Cambridge Union Notes, 11 February. The John Maynard Keynes Papers, OC/5/210. Cambridge, U.K.: King's College.

- (1923). John Maynard Keynes to Lydia Lopokova, 9 December. The John Maynard Keynes Papers, PP/45/190/1/55. Cambridge, U.K.: King's College.

- (1924c). Prolegomena to a New Socialism. The John Maynard Keynes Papers, P/6/24. Cambridge, U.K.: King's College. 
- (1924b). Policy Divisions Between the Liberal and Labour Parties. The John Maynard Keynes Papers, A/24/150. Cambridge, U.K.: King's College.

- (1925). John Maynard Keynes to Kurt Singer, 23 April. The John Maynard Keynes Papers, NS/1/1/229. Cambridge, U.K.: King's College.

- (1926). Laissez-Faire and Communism. New York: New Republic, Inc.

- (1927a). John Maynard Keynes to Lydia Lopokova, 16 October. The John Maynard Keynes Papers, PP/45/190/3/241. Cambridge, U.K.: King's College.

- (1927b). John Maynard Keynes to Lydia Lopokova, 16 October. The John Maynard Keynes Papers, PP/45/190/3/257. Cambridge, U.K.: King's College.

- (1928a). Debate: That the Socialist Solution to the Economic Evils of Today is to be Preferred to that Contained in the Liberal Industrial Report. The John Maynard Keynes Papers, PS/4/109-16. Cambridge, U.K.: King's College.

- (1928b). Resolution to Establish a National Investment Board. The John Maynard Keynes Papers, PS/4/65-80. Cambridge, U.K.: King's College.

- (1929). Social Reform as the New Socialism. The John Maynard Keynes Papers, PS/4/187-91. Cambridge, U.K.: King's College.

- (1931). Reports of Round Tables: Unemployment as a World-Problem. Chicago: Norman Wait Harris Memorial Foundation: 484-504.

- (1933a). Lecture at Cambridge, 6 November. In Rymes (Ed.) Keynes's Lectures, 1932-35: Notes of a Representative Student. London: Macmillan, 1989.

- (1933b). Mr. Keynes's Control Scheme. American Economic Review, 23 (4): 675.

- (1940). Speech to the Fabian Society: How to Pay For the War. The John Maynard Keynes Papers, HP/2/99. Cambridge, U.K.: King's College.

- (1942). John Maynard Keynes to Joan Robinson, 20 August. The John Maynard Keynes Papers, L/42/102. Cambridge, U.K.: King's College. 
- (1946). John Maynard Keynes to Hugh Molson, 24 January. The John Maynard Keynes Papers, L/46/35. Cambridge, U.K.: King's College.

- (1943). John Maynard Keynes to Bernard Shaw, 4 May. The John Maynard Keynes Papers, PP/45/291/21. Cambridge, U.K.: King's College.

- (1971-89). The Collected Writings of John Maynard Keynes, vols. 1-30. London: Macmillan and Cambridge University Press for the Royal Economic Society.

- (1988). Keynes's Lectures, 1932-35: Notes of Students. Rymes (Ed.). Unpublished Typescript.

- (1989). Keynes's Lectures, 1932-35: Notes of a Representative Student. Rymes (Ed.). London: Macmillan.

KING, J.E. (2002). A History of Post Keynesian Economics Since 1936. Cheltenham, U.K.: Edward Elgar.

KLEIN, L.R. (1949). The Keynesian Revolution. London: Macmillan, 1968.

Labour Party. (1928). Labour and the Nation. London: Labour Party.

- (1934). For Socialism and Peace: The Labour Party's Programme of Action. London: Labour Party.

LAIDLER, D.E. (1999). Fabricating the Keynesian Revolution. New York: Cambridge University Press.

LAMbert, P. (1963). The Social Philosophy of John Maynard Keynes. Annals of Public and Cooperative Economics, 34 (4): 483-515.

Lange, O.R. (1938). The Rate of Interest and the Optimum Propensity to Consume. Economica, 5 (17): 12-32.

LAURENT, J. (2001). Keynes and Darwinism. In Laurent and Nightingale (Eds.). Darwinism and Evolutionary Economics. Northampton, MA: E. Elgar.

LaWlor, M.S. (2006). The Economics of Keynes in Historical Context. New York: Palgrave Macmillan.

Leijonhufvud, A. (1968). On Keynesian Economics and the Economics of Keynes: A Study in Monetary Theory. New York: Oxford University Press.

Lekachman, R. (1966). The Age of Keynes. New York: Random House

- (1985). The Radical Keynes. In Wattel (Ed.), The Policy Consequences of John Maynard Keynes. Armonk, N.Y.: M.E. Sharpe: 3038. 
Lenin, V.I. (1960-70). V.I. Lenin Collected Works, vols. 1-45. Moscow: Progress Publishers.

Letiche, J.M. (1971). Soviet Views on Keynes: A Review Article Surveying the Literature. Journal of Economic Literature, 9 (2): 442-58.

LitTleboy, B. 1990. On Interpreting Keynes: A Study in Reconciliation. New York: Routledge.

Lopokova, L. (1922). Lydia Lopokova to John Maynard Keynes, 18 April. The John Maynard Keynes Papers, PP/45/190/9/29. Cambridge, U.K.: King's College.

MACKRell, J. (2008). Bloomsbury Ballerina: Lydia Lopokova, Imperial Dancer and Mrs John Maynard Keynes. London: Weidenfeld \& Nicolson.

Martin, K. (1970). Editor: «New Statesman» Years, 1931-1945. Chicago: Henry Regnery Company.

MARX, K. (1848). Economic and Philosophic Manuscripts of 1844 and the Communist Manifesto. Amherst, N.Y.: Prometheus Books, 1988.

McKibBin, R. (2013). Political Sociology in the Guise of Economics: J.M. Keynes and the Rentier. English Historical Review, 128 (530): 78-106.

Meade, J.E. (1933). Public Works in Their International Aspect. London: The New Fabian Research Bureau.

- (1937). A Simplified Model of Mr. Keynes' System. The Review of Economic Studies, 4 (2): 98-107.

Meltzer, A.H. (1988). Keynes's Monetary Theory: A Different Interpretation. New York: Cambridge University Press.

- (1992). Patinkin on Keynes and Meltzer. Journal of Monetary Economics, 29: 151-162.

Milgate, M. (1982). Capital and Employment. New York: Academic Press.

MinI, P.V. (1991). Keynes, Bloomsbury, and the General Theory. New York: St. Martin's Press.

MinsKY, H.P. (1975). John Maynard Keynes. New York: Columbia University Press.

Mises, L.V. (1922). Socialism: An Economic and Sociological Analysis. Indianapolis: Liberty Fund, 1981.

- (1927). Liberalism: The Classical Tradition. Indianapolis: Liberty Fund. 
- (1929). A Critique of Interventionism. New Rochelle, N.Y: Arlington House, 1977.

- (1944). Omnipotent Government. Indianapolis: Liberty Fund, 2011.

- (1949). Human Action: A Treatise on Economics. Scholar's Ed. Auburn, A.L.: Ludwig von Mises Institute, 1998.

- (1952). Planning for Freedom. Indianapolis: Liberty Fund, 2008.

- (1990). Economic Freedom and Interventionism. Indianapolis: Liberty Fund.

Moggridge, D.E. (1973). From the Treatise to The General Theory: An Exercise in Chronology. History of Political Economy, 5 (1): $72-$ 88.

- (1976). John Maynard Keynes. New York: Penguin Books.

- (1992). Maynard Keynes: An Economist's Biography. London: Routledge.

- (1992). Richard Kahn as an Historian of Economics. Cambridge Journal of Economics, 18 (1): 107-16.

- (2002). Skidelsky on Keynes. History of Political Economy, 34 (3): 633-55.

NAYLOR, T.H. (1968). A Note on Keynesian Mathematics. Economic Journal 78 (309): 172-73.

Mosley, O. (1936). Fascism: 100 Questions Asked and Answered. London: Black House Publishing, 2012.

Newton, S. (2001). Deconstructing Harrod: Some Critical Observations on The Life of John Maynard Keynes. Contemporary British History, 15 (2): 15-27.

O'Donnell, R.M. (1989). Keynes: Philosophy, Economics, and Politics. New York: St. Martin's Press.

- (1990). Keynes on Mathematics: Philosophical Foundations and Economic Applications. Cambridge Journal of Economics, 14 (1): 29-47.

- (1991). Keynes's Political Philosophy. In Barber (Ed.), Perspectives on the History of Economic Thought, Vol. 5. Aldershot: Edward Elgar: 3-28.

- (1992). The Unwritten Books and Papers of J.M. Keynes. History of Political Economy, 24 (4): 767-817.

- (1999). Keynes's Socialism: Conception, Strategy, and Espousal. In Kriesler and Sardoni (Eds.), Keynes, Post-Keynesianism and Po- 
litical Economy: Essays in Honour of Geoff Harcourt, Vol. 3. London: Routledge: 149-75.

OpIE, R. (1974). The Political Consequences of Lord Keynes. In Moggridge (Ed.), Keynes: Aspects of the Man and his Work. London: Macmillan: 75-101.

Patinkin, D. (1976). Keynes' Monetary Thought: A Study of its Development. Durham, N.C.: Duke University Press.

- (1977). The Process of Writing the General Theory. In Leith and Patinkin (Eds.), Keynes, Cambridge, and the General Theory. London: Macmillan: 3-24.

- (1982). Anticipations of the General Theory? Chicago: University of Chicago Press.

- (1987). Keynes, John Maynard (1883-1946). In Eatwell, Milgate and Newman (Eds.), The New Palgrave Dictionary of Economics. New York: Palgrave Macmillan: 19-41.

- (1990). On Different Interpretations of the General Theory. Journal of Monetary Economics, 26: 205-43.

- (1994). Mr Meade's Relation, Kahn's Multiplier and the Chronology of the General Theory: Reply. Economic Journal, 104 (426): 1143-46.

Perelman. (1989). Keynes, Investment Theory, and the Economic Slowdown. New York: St. Martin's Press.

Pimlott, B. (1985). Hugh Dalton. London: Jonathan Cape.

PresLey, J.R. (1979). Robertsonian Economics: An Examination of the Work of Sir D.H. Robertson on Industrial Fluctuation. New York: Holmes and Meier.

Preston, R.H. (1987). The Ethical Legacy of John Maynard Keynes. In Reese (Ed.), The Legacy of Keynes. San Francisco: Harper \& Row: 146-78.

Pugh, P. (1984). Educate, Agitate, Organize: 100 years of Fabian Socialism. New York: Methuen.

RaIco, R. (2008). Was Keynes a Liberal? The Independent Review, 13 (2): $165-88$.

RedDaway, W.B. (1936). The General Theory of Employment, Interest and Money. Economic Record, 12: 28-36.

Robertson, D.H. (1931). Mr. Keynes' Theory of Money. Economic Journal, 41 (163): 395-411. 
Robinson, A. (1947). John Maynard Keynes 1883-1946. Economic Journal, 57 (225): 1-68.

- (1977). Keynes and his Cambridge Colleagues. In Leith and Patinkin (Eds.), Keynes, Cambridge, and the General Theory. London: Macmillan: 25-38.

Robinson, J. (1966). An Essay on Marxian Economics. London: Macmillan.

- (1971). Economic Heresies. New York: Basic Books.

Rosenbaum, S.P. (2003). Georgian Bloomsbury. The Early Literary History of the Bloomsbury Group. New York: Palgrave Macmillan.

Rosner, V. (2014). The Cambridge Companion to the Bloomsbury Group. New York: Cambridge University Press.

Rowse, A.L. (1932). Mr. Keynes on Socialism: A Reply. The Political Quarterly, 3 (3): 409-15.

- (1936). Mr. Keynes and the Labour Movement. London: Macmillan. SALERNO, J.T. (1992). The Development of Keynes's Economics: From

Marshall to Millennialism. The Review of Austrian Economics, 6 (1): 3-64.

SAMUELSON, P.A. (1983). Marx, Keynes, and Schumpeter. Eastern Economic Journal, 9 (3): 166-79.

- (1990). Paul A. Samuelson. In Blaug (Ed.), John Maynard Keynes: Life, Ideas, Legacy. New York: St. Martin's Press: 55-63.

SchUKer, S.A. (2014). J.M. Keynes and the Personal Politics of Reparations: Part 1. Diplomacy \& Statecraft, 25: 453-71.

Schumpeter, J.A. (1943). Capitalism, Socialism and Democracy. New York: Routledge, 2006.

- (1946). John Maynard Keynes 1883-1946. The American Economic Review, 36 (4): 495-518.

SHACKLE, G.L.S. (1974). Keynesian Kaleidics. Edinburgh: Edinburgh University Press.

SheeHan, B. (2009). Understanding Keynes' General Theory. New York: Palgrave Macmillan.

SKIDELSKY, R. (1975). Oswald Mosley. London: Papermac, 1990.

- (1983). John Maynard Keynes: Hopes Betrayed, 1883-1920. New York: Viking, 1986.

- (1991). Keynes's Philosophy of Practice and Economic Policy. In O'Donnell (Ed.), Keynes as Philosopher-Economist. London: Macmillan: 104-23. 
- (1992). John Maynard Keynes: The Economists as Savior, 1920-1937. New York: Viking, 1994.

- (1998). The American Response to Keynes. In Thirlwall (Ed.), Keynes and Laissez-Faire. London: Macmillan: 79-99.

- (2000). John Maynard Keynes: Fighting for Freedom, 1937-1946. New York: Viking, 2001.

- (2009). Keynes: The Return of the Master. New York: PublicAffairs.

Smith, A. (2004). Martin, (Basil) Kingsley (1897-1969). Oxford Dictionary of National Biography, Oxford University Press.

Solow, R.M. (1984). Mr Hicks and the Classics. Oxford Economic Papers, 36 New Series Supplement Economic Theory and Hicksian Themes: 13-25.

- (1991). Keynes Lectures; Review. Economic Journal, 101 (407): 97172.

SteELE, G.R. (2007). The Economics of Friedrich Hayek. New York: Palgrave Macmillan.

STRACHEY, L. (2005). The Letters of Lytton Strachey. New York: Farrar, Straus and Giroux.

SwEEzY, P.M. (1946). John Maynard Keynes. Science \& Society, 10 (4): 398-405.

TAunton, M. (2013). The Stalin-Wells Talk: the Interview that Defined the Post-War British Left. New Statesman, 18 July 2013.

ToBIN, J. (1996). Essays in Economics, Vol. 4. Cambridge, M.A.: MIT Press.

ToYe, R. (1999). Keynes, the Lobour Movement, and 'How to Pay for the War'. Twentieth Century British History, 10 (3): 255-81.

- (2005). The Trials of a Biographer: Roy Harrod's Life of John Maynard Keynes. In Gottlieb and Toye (Eds.), Making Reputations: Power, Persuasion and the Individual in Modern British Politics. London: I.B. Tauris: 123-34.

WALKER, G.S. (1988). Thomas Johnston. New York: Manchester University Press.

Weвв, B. (1985). The Diary of Beatrice Webb, Vol. 4: The Wheel of Life 1924-1943. Cambridge, Mass: Belknap Press of Harvard University Press.

Woolf, V. (1978). The Letters of Virginia Woolf, Vol. 3: 1923-1928. New York: Harcourt Brace Jovanovich. 
- (1985). The Letters of Virginia Woolf, Vol. 5: 1932-1935. New York: Harcourt Brace Jovanovich.

YDE, M. (2013). Bernard Shaw and Totalitarianism: Longing for Utopia. New York, NY: Palgrave Macmillan.

Young, W. (1987). Interpreting Mr. Keynes: The IS-LM Enigma. Boulder, Colorado: Westview Press. 